\title{
Gyôri Zsolt
}

\section{Magyar Egyetemi Filmdíj: lehetséges fogalmi keretek és tanúságok (2019/2021)}

\begin{abstract}
Absztrakt
Tanulmányomban az elsô ízben idén megszervezett Magyar Egyetemi Filmdíj (MEF) koncepcióját, a kezdeményezés forrásait, pedagógiai céljait vizsgálom, és a lebonyolítás során szerzett tapasztalatokat felhasználva a versenyfilmeket elemzem. Célom a 2019-es év magyar filmtermésébôl a MEF szervezôi által közösen kiválasztott hat alkotás közös metszeteinek és megkülönböztetô jegyeinek a feltárása, mely vetületek kijelölésekor a kritikai és pedagógiai feldolgozás mikéntje és mintázata, a problémaérzékenység fejlesztésének a keretei is meghatározására kerülnek. A listán szereplő filmek értelmezésemben a kortárs magyar filmkultúrában zajló esztétikai, múfaji és társadalomábrázolási folyamatokat teszik olvashatóvá, egyfelól a múvészfilmes és múfajfilmes beszédmódok keveredését, másfelől a magyar film fesztivál- és közönségsikereire, avagy azok hiányára magyarázatot kínáló tematikai csomópontok létrejöttét és átalakulását. A tanulmány két csoportba sorolva vizsgálja a filmeket és a fentebb említett szempontokon túl azt vizsgálja, hogy az egyes alkotások trauma-ábrázolása mennyiben járul, vagy nem járul hozzá a válságtapasztalatok iránt érzékeny nyilvánosság kialakulásához, a társadalmi mentalitások megértéséhez, formálásához.
\end{abstract}

\section{Szerző}

Gyôri Zsolt a Debreceni Egyetem Angol-Amerikai Intézetében adjunktus, itt szerezte PhD fokozatát is. Kiemelt kutatási területei közé tartozik a film és társadalom, a történelem és az emlékezet filmes ábrázolása, különös tekintettel a brit és a magyar filmtörténetben. A brit moziról antológiát (Fejezetek a brit film történetéból, 2010) szerkesztett, míg a rendszerváltás utáni magyar mozi kultúratudományos megközelítéseit kínáló kötetek (Test és szubjektivitás a rendszerváltás utáni filmben, Tér, hatalom és szubjektivitás viszonyai a magyar filmben, Nemek és etnikumok terei a magyar filmben, Europe and European Cinema at Times of Change) társszerkesztöje. Filmek, szerzók, kritikaiklinikai olvasatok címú monográfiája 2014-ben jelent meg, a Travelling around Cultures: Collected Essays on Literature and Art címú valamint a Postsocialist Mobilities címú társszerkesztett kötete 2016ban, valamint 2021-ben (Cambridge Scholars Press). Ewa Mazierskával közösen szerkesztett kötetei: Popular Music and the Moving Image in Eastern Europe (Bloomsbury, 2018), Eastern European Popular Music in a Transnational Context 
(Palgrave, 2019). A Hungarian Journal of English and American Studies folyóirat szerkesztôje.

E-mail: gyorizs@yahoo.co.uk

https://doi.org/10.31176/apertura.2021.16.4.2 


\section{Gyóri Zsolt}

\section{Magyar Egyetemi Filmdijj: lehetséges fogalmi keretek és tanúságok (2019/2021)}

\section{A Magyar Egyetemi Filmdíj gondolatának forrásai és az alapítói célok}

Több hónapos elôkészítô munka után a 2020/2021 tanév tavaszi félévében 8 magyar, illetve magyar nyelvú képzést kínáló erdélyi felsôoktatási intézmény több mint száz hallgatójának a részvételével került sor az elsô Magyar Egyetemi Filmdíj (a későbbiekben MEF) elôzsûrizési folyamatára: a filmek közös megnézésére, megvitatására és objektív mérce szerinti értékelésére. [1] Én a Debreceni Egyetemet képviselve egy hibrid formájú, szemináriumként is múködô filmklub oktatójaként és vezetójeként vettem részt a kezdeményezésben, melynek keretében hat 2019-ben bemutatott film került feldolgozásra. A válogatás azért esett a 2019-es évre, mert a pandémia miatt a filmgyártás is leállt, a forgatások és bemutatók csúsztak, illetve elmaradtak, így 2020-ban egyszerúen nem készült kellô számú film a lebonyolításhoz. Fontos szempontot jelentett az is, hogy a nem tárgyévben bemutatott filmek vetítési jogainak a megszerzése könnyebbnek bizonyult. A lista naptári év alapon történô meghatározása jól értelmezhetô látleletet kínál a magyar moziról, láthatóvá teszi tendenciáit, közös kérdéseit és hangsúlykülönbségeit. Emellett összhangban áll a filmdíjak odaítélésének nemzetközi gyakorlatával és a MEF számára modellként szolgáló 2016-ban alapított Európai Egyetemi Filmdíj (a késôbbiekben, az eredeti elnevezés alapján EUFA) lebonyolítási módjával.

Az EUFA röviden és tömören megfogalmazott küldetése így hangzik: „A nacionalizmus térnyerése Európában és a világ más részein arra ösztönzött minket, hogy felkutassuk az európai egyetértést elôsegítô közös elemeket, valamint a kulturálisan, mindenekelött a filmkultúra által meghatározott európai identitást." [2] A 2020-as kiírásban az eredeti 13 intézmény helyett már 25 ország egyetemének egy delegált hallgatói képviselôje vett részt a Hamburgban workshop formában megtartott végsố tanácskozáson, ahol az öt versenyben lévő film esztétikai és tematikai erényeit vitatták meg és vetették össze, magyarán kidolgozták a díjazás szempontrendszerét. A nyertes alkotást az Európai Filmdijj gáláján hirdetik ki minden év decemberében a közönségdíj kategóriájában.

Magyarországot a Pázmány Péter Katolikus Egyetem képviselte a kezdetektôl, míg Romániát 2017tôl a Sapientia Erdélyi Tudományegyetem. A lebonyolításban szerzett jelentôs tapasztalatoknak köszönhetôen, evidensnek tûnt, hogy Pócsik Andrea koordinálja a MEF lebonyolításának különböző fázisait, ráadásul a Magyar Filmtudományi Társaság (a késôbbiekben MFT) ${ }^{[3]}$ 
Módszertani Munkacsoportjának vezetójeként ô a kezdeményezés ötletgazdája. A EUFA modell adaptálása során a filmmúvészet páneurópai kerete módosult, de „a közös értékek és eszmények mentén való közös gondolkodás, a világ és egymás megértésének igénye, valamint a nemzeti, társadalmi és sztereotip bélyegek elleni küzdelem" ${ }^{[4]}$ a nemzeti keretben is lényegi cél maradt.

A koncepció honosításának legelsô lépcsôjét a filmek kiválasztása jelentette. A kurzusokat és filmklubokat vezetô oktatók az alábbi hat, 2019-es filmet jelölték ki: FOMO (Hartung Attila), Szép csendben (Nagy Zoltán), Akik maradtak (Tóth Barnabás), Apró mesék (Szász Attila), Csak családról ne (Kis Anna) és A létezés eufóriája (Szabó Réka). Az EUFA-s filmválogatásokhoz hasonlóan dokumentumfilmek is szerepeltek a listán \Kis és Szabó filmje \ hiszen a dokumentumfilm mindig is integráns része volt a magyar filmkultúrának. Bár a kétezres évek elején jelentôsége visszaesett, az elmúlt években több, nagy közönségsikert magáénak tudható film készült. Másfelôl a dokumentumfilmnek hagyományosan erôs a társadalmi elkötelezôdése és tünetszerúen képezi le az adott kor dinamikáját, közbeszédet meghatározó problémáit, értékválságát és értékkonfliktusait.

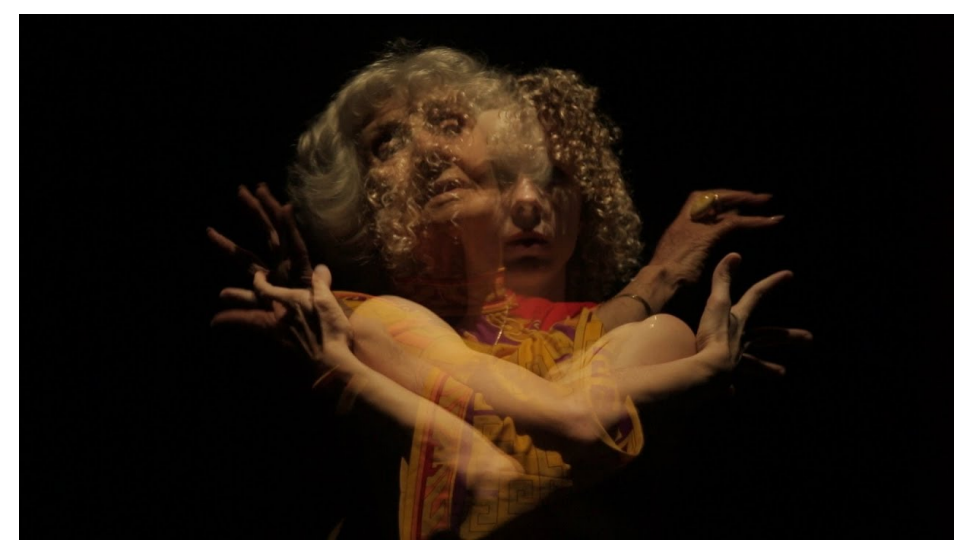

A létezés eufóriája a Sóvirág táncszinházi elöadás elôkészületeinek felvételeiböl született meg.

Az EUFA és a MEF lebonyolítása egyaránt két szinten történik. Egyfelôl a feldolgozásra és megvitatásra kerülő filmek listáját a filmes tárgyakat oktató szervezők állítják össze, de a diákok határozzák meg a végsô sorrendet. A kiválasztási és értékelési folyamat generációk szerinti elkülönítése és az eltérô értékpreferenciák érvényesülése természetesen feszültséget is teremt. A 20-as éveik elején járó hallgatók filmes preferenciája még akkor is különbözik középkorú tanáraikétól, ha kortársaiknál elmélyültebb kapcsolatuk van a mozival, több és többféle filmet néznek és vitatnak meg. ${ }^{[5]}$ Ugyanakkor legtöbbjük sorozatot és online mozgóképes tartalmat néz, a magyar filmekkel kapcsolatos elóítéletek még a filmkultúra iránt elkötelezett hallgatók körében is jellemzôek. Rájuk is igaz Hartai megállapítása, miszerint „a magyar film nyílt és büszkén vállalt elutasítását a fiatalok körében inkább egyfajta gyanakvás válthatta fel a hazai filmekkel szemben.” [6

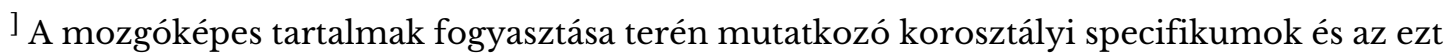
magyarázó különbségek az értékrend, az élettapasztalat és az életmód tekintetében feszültséget jelentenek, de ez inspiráló feszültség. Természetesen nem mindegy, hogy a Kádár-rendszerben, a rendszerváltást követô évtizedben vagy a kétezres években szocializálódtunk, és alakultak ki filmes preferenciáink, mindenesetre az ízlésbeli különbségek ütköztetése mindkét korcsoport számára 
motiváló lehet: gondolatébresztô beszélgetések lehetôségét rejti.

Minél sokszínúbb értékpreferenciák, identitásstratégiák és generációs élmények jelennek meg a filmben, annál inkább hasznosak a beszélgetések és a viták. Nem csak az európaiság kapcsán lehet elmondani azt, hogy ahány ország, annyi módon él az öreg kontinens az emberek képzeletében, válik önmeghatározásuk részévé, illetve jelöl ki közös horizontokat vagy határokat. Az európai identitás megélésének más diskurzusai léteznek a turizmus dominálta délen, a gazdasági migráció társadalmi hatásainak kitett keleti régiókban, a jóléti társadalom mellett elkötelezett északi országokban és a globális politikai és kereskedelmi vérkeringésbe leginkább integrálódott nyugaton. A magyar identitás ugyancsak többalakú: megélésének számtalan, gyakran egymással versengó és egymásnak ellentmondó módja, rítuskészlete, (szub)kultúrája van. Mást jelent magyarként európainak lenni a vidéken és a városokban, de jelentôs különbségek vannak Nyugatés Kelet-Magyarország között, de még azon belül is. Mindezen különbségeket nem nehézségeknek, hanem lehetôségeknek tekintettük. A filmek kiválasztásánál az elkövetkező években is a változatosságra kell törekednünk, feltéve, ha ezt a változatosságot az éves filmtermések is beigazolják. A magyar film intézményes és finanszírozási hátterének évtizedes kiszámíthatatlansága az elkészült filmek számában lehet, hogy meglátszik, de szerencsére eddig nem vezetett egyszínúséghez.

A szükségesnél talán hosszabb bevezetôvel azt szerettem volna érzékeltetni, hogy a MEF a véleménycserét, a tapasztalatok pluralitását érvényesítô tanulási környezet megerôsítésére tesz kísérletet az egyre inkább tömegképzésre specializálódott felsôoktatás világában. Pócsik megfogalmazásában „[a] projekt egyik legnagyobb elő́nye a vitakultúra fejlesztése, amelyre Magyarországon a többnyire frontális és tekintélyelvú oktatási rendszerben égetô szükség van”. [7] A Magyar Filmtudományi Társaságnak a kezdeményezést bemutató ismertetôje a módszertani megújulás mellett a projekt során fejlesztésre kerülő készségekre helyezi a hangsúlyt: „az újonnan születô alkotásokkal kapcsolatos tudatosság növelése, elemzői, kritikai attitűd erôsítése, az aktuális filmtermésben való jártasság növelése, a magyar filmkultúra egészének mélyebb, analitikusabb ismerete, a filmkritikai íráskészség fejlesztése, a tudatos, reflexív filmbefogadás erôsítése." [8] Mindezek a célok az egyetemi filmoktatásba éppúgy integrálhatóak, mint a hallgatói részvétellel és (helyenként) szervezéssel múködő filmklubok moderált beszélgetéseibe. A filmek feldolgozásához az MFT által kínált irányelvek - úgymint az aktualitás, a problémafelvetés kidolgozottsága, az újszerúség, a filmnyelvi és dramaturgiai értékek, valamint az egyetemes filmkultúra iránti tudatosságban megragadott nemzeti jelleg - állnak legközelebb a versenyfilmek kiválasztásánál érvényesítendô kritériumrendszer megfogalmazásához.

Tudnunk kell tehát, hogy mi célból és milyen feldolgozási módszereket használva akarunk filmekrôl beszélni, de ez önmagában még nem elég. Azokat is ismernünk kell, akikkel beszélgetni akarunk a filmekrôl, akiknek a készségeit fejleszteni akarjuk. Újra Pócsikot idézem: „egy film kiválasztásakor annak poétikáját és politikáját vesszük figyelembe - azt tehát, ahogy a feldolgozott téma és a feldolgozás mikéntje rezonál Európa társadalmi, politikai és kulturális valóságával ugyanakkor a filmválasztással a nézőre gyakorolt hatást is megjósoljuk.” ${ }^{[9]}$ Ez a gondolat pontosan 
ragadja meg a mindenkori filmklub-szervezô egyik legnagyobb dilemmáját, a közönség megszólításának és aktivizálásának a nehézségét. A „Romakép Múhely” [10], egyetemi kurzusként és közösségi filmklubként múködő múhely alapítójaként Pócsik, akárcsak a projektben részt vevő valamennyi, filmklubszervezési tapasztalattal rendelkezô oktató, pontosan tudja, hogy egy évad filmjeinek a kiválasztásakor a nézőre gyakorolt hatás megjósolása mennyire fontos. Ismernünk kell a közönség elvárásait, esztétikai preferenciáit, a fiatalok körében forró témákat és hívószavakat, melyek beindítják a beszélgetést. A közönség ismerete a véleménycserében megvalósuló közösségi dinamika értését és irányítását is magába foglalja: egy film megértésének már az is része, amilyen nézői reakciót kivált, és amilyen vitát generál. Jelen tanulmány amellett érvel, hogy a filmek kiválasztása, avagy a „mit nézzünk”, „mit hasonlítsunk össze” kérdéseit döntôen befolyásolják a „mi célból vetítünk filmeket”, a „hogyan dolgozzuk fel ôket” és a „kik értelmezik a filmeket" kérdései. A három utóbbi kérdésre a MEF kezdeményezés már a tervezés idôszakában meglehetôsen konkrét válaszokat adott: konstans és állandó tényezőknek tekinti ôket. Nem így az évrôl-évre változó filmlistára, melynek összeállítása legalább olyan komoly fejtörést és felelôsséget jelent a szervezôk számára, mint a hallgatóknak a gyôztes alkotás kiválasztása. Nem ez lenne a helyzet, ha az összeállításkor objektív szempontokat érvényesítettünk volna, és mondjuk, a legnagyobb nézôszámot elérő, legmagasabb nézôi értékeléssel bíró vagy a legnagyobb költségvetéssel rendelkező filmek kerülnének automatikusan a listára. Az elsô évben inkább a félszubjektív szempontok adtak támpontot: a filmkritikai fogadtatást, a hivatásos értelmezôk tetszésindexét is figyelembe véve, azokat a szervezôk személyes preferenciáival vegyítve jutottunk konszenzusra a filmlista kapcsán.

A 2021-es MEF kapcsán szerveződô egyetemi kurzusok és filmklubok nem abban az értelemben nevezhetôek tematikus vetítéssorozatnak, hogy egy hangzatos narratíva mentén koherens problémacsokrot kívánnak átnyújtani a közönségnek. Tematikusságot leginkább a történeti, pontosabban a „csonka történeti” jelleg kölcsönöz a filmválogatásnak, ami azért rendhagyó módon csonka, mert egy évnyi filmtermés köré a múltban aligha szervezôdött oktatási vagy népszerūsítôi tevékenység. Ez most megváltozott és a projekt folytatása biztosítja e rendhagyó forma jövôjét és, remélhetôleg, annak legitimitását is. A kiválasztási szempontok esetlegessége ellenére sem mondható az, hogy a hat film tematikailag összeegyeztethetetlen, hogy a korpuszra helyezhetô fogalmi keret teljesen széttartó, és az értelmezést szolgáló „kritikai narratívának” nincsenek csomópontjai. A kritikai gondolkodás gyakorlásának és fejlesztésének pedagógiai célját a problémaérzékenység összehasonlíthatósága, valamint a közös témafelvetések eltérô filmnyelvi prezentációjának a megvitatása jelentette, mindenekelôtt pedig az, hogy az összehasonlíthatóság történeti, múfaji, recepciós-intézményes, filmnyelvi és fogalmi keretét, módszertanát kidolgozzuk. Mindezek részletes megvitatására terjedelmi és szakértelembeli korlátok miatt nem vállalkozik jelen szöveg. Az elkövetkezőkben három területre koncentrálok: (1) az egyre múfajtudatosabbá váló magyar filmkultúra példáiként vizsgálom az alkotásokat; (2) az alapján hasonlítom össze a két csoportra osztott filmeket, ahogy nemzetköziesítenek, avagy honosítanak társadalmi témákat, ahogy beemelôdnek a nemzetközi rendszerbe, illetve kirekesztôdnek onnan; (3) a korábbi felosztást megtartva a traumatapasztalatok társadalmasításának a kérdése felól 
közelítek a filmekhez és az alapján vetem óket össze, ahogy közösségi értékrendünkben és önértelmezésünkben elhelyezik a traumatikus élményeket.

Az összehasonlítás fentebbi szempontjai mellett számos más legitim elemzési módszertan létezik. Az általam tartott kurzus és filmklub résztvevôi nem vesznek részt filmes szakként szervezett filmtudományi képzésben, egy részük a magyar filmmel ismerkedô külföldi hallgató. A hat film összehasonlíthatóságát biztosító keretek emiatt egyediek, pedagógiai hasznosságukat a magyar filmkultúra társadalomtudatosságának a hangsúlyozásából nyerik.

\section{A MEF mint egy kis nemzeti filmmúvészet díja}

A díj elnevezése földrajzilag egyértelmúen megjelöli a helyszínt, Magyarországot, ugyanakkor lokális környezetbe helyez egy nemzetek feletti kezdeményezést. Egyszerre kötelezôdik el a kulturális-filmes rendszer nemzeti és európai kerete iránt, a filmkultúrát ezek érintkezési pontjaként, ezek egyezkedéseként tételezi. Ez a köztes állapot, kapcsolatteremtô képesség a kis nemzeti mozik (small national cinemas) fontos vonása. A Mette Hjort és Duncan Petrie nevéhez fúzôdô kis nemzeti mozi fogalma persze sokkal általánosabb kritériumokból indul ki: az ország területének mérete, lakosainak száma, a nemzeti össztermék, szuverenitáshiányos történelmi tapasztalat. ${ }^{[11]}$ A megközelítés újdonsága, hogy az elszigetelődés és a kozmopolitizmus mechanizmusait nem ellentétpárként használja, a nemzeti filmipart nem állítja szembe a domináns globális filmiparral. A szerzốk megfogalmazásában „a nemzeti filmpolitikák napjainkban kevésbé törekszenek a helyi gyártás és kultúra feltétlen védelmére és az amerikanizáció réme sem annyira fenyegető, mint korábban; a protekcionizmusnál fontosabb lett az új globális munkamegosztás kínálta, vélt elônyök kiaknázása." [12] Ilyen elônyöket kínálnak Magyarországon a nagy költségvetésú hollywoodi bérmunkák (runaway production), melyek nyomán infrastrukturális beruházások valósulhattak meg, a helyi szakma értékes munkatapasztalatot nyer, és értékes referenciákhoz jut. A hazai szakemberek testközelből tapasztalják meg az európai filmgyártás pragmatikus szemléletét, miszerint, ha szükséges, versenyez, ha szükséges, együttmúködik Hollywooddal: anélkül kínál hozzáférést fizikai és humán erőforrásaihoz, hogy feladná a filmfinanszírozás nemzeti keretét. ${ }^{[13]}$ Persze a magyar kis nemzeti filmgyártást aligha tekinthetjük a Hollywooddal versenyezni képes filmiparnak, hiszen még a hazai mozikban sem ugyanazon a terepen játszanak. A Vajna-korszak támogatási rendszere (20122019), a forgatókönyvek elôkészítésére helyezett nagyobb hangsúllyal maga is a pragmatizmust képviselte a filmkészítés kreatív gyakorlataiban. A MEF a globális és európai hatások felerôsödését eredményezô évtized végén kínál pillanatfelvételt a magyar filmkultúráról, ám a szigorú értelemben vett szakmai kihívások mellett a társadalmi krízishelyetek okozta értékválsággal (2008as hitelválság, migránsválság, \#MeToo mozgalom, globális éghajlati válság, mélyszegénység, stb.) is szembe kellett néznie. Ezek közül többnek a hatása a 2019-es év filmtermésében koncentráltan jelent meg, mintegy bizonyítva a kis nemzeti filmkultúrák egyetemes tényezốk iránti nyitottságát.

A filmes beszédmódokban a globális hatások olyan hibridizációt eredményeztek, amit Andrew 
Nestingen „a múfajfilm gördülékeny stílusát és dramaturgiai eszköztárát a többletjelentéseket felkaroló múvészfilmes ábrázolásmóddal vegyítô” [14] „közép-komoly múfajfilm” (mediumconcept film) fogalma jelöl. ${ }^{[15]} \mathrm{Az}$ alkotói stílus és a szerzôi film évtizedes hazai dominanciájának ismeretében nem szükséges hosszan ecsetelnem, mennyire mélyen gyökerezik a többletjelentések iránti igény a magyar filmesek és a múvészi kvalitások iránt érzékeny közönsége soraiban. Az évtized végén a közép-komoly múfajfilm fogalma mégis relevánsabb, mint bármikor korábban. A Film Genres in Hungarian and Romanian Cinema címú, frissen megjelent monográfiájában Virginás Andrea a fogalom Nestingen kínálta definícióját kifordítja és a múfaji filmek múvészfilmes módosulásai helyett a múvészfilmek múfajfilmes elemekkel történô hibridizációjáról beszél: „a múvészfilmes beszédmód... korábban ismeretlen, múfajspecifikus elemekkel egészül ki. Ilyen az irónia, a »filozofikus és politikai elköteleződés« gyengülése, a dinamikus cselekményvezetés, a lélektani ábrázolás sekélyesebbé válása és a pszichologizálás fellazulása, valamint konkrét múfajok kliséire történô nyílt »utalások«." [16]

A MEF listából versenyben lévô négy játékfilm jól szemlélteti a fentebb jellemzett hibrid jelleget. Alkotóik pályafutásuk elején járnak: a szóban forgó filmek elsó vagy második, moziban vetített rendezésük. A múfajfilm fontos szerepet játszott mozgóképes szocializációjukban, melyet pozitív hatásként emlegetnek, ugyanakkor a többletjelentésekben gazdag és nagyobb értelmezôi szabadságot biztosító múvészfilmet is fontos referenciapontként említik. A filmjében érintett társadalmi probléma kapcsán Nagy Zoltán személyes tinédzserkori érintettségét említi, emellett azt hangsúlyozza, hogy pszichológusok, kriminológusok, jogászok és zaklatási ügyben jártas, más szakemberek segítették a forgatókönyvírást. Az ábrázolt konfliktus múvészfilmes érzékenységet hangsúlyozó többszempontú megértése a felnôtté válás (coming of age) múfaji formulával keveredik, és - mint Nagy maga is kiemeli - a célközönség fôszereplőkkel történő azonosulását segíti: „elsôsorban a filmben szereplő fiatalok kortársainak szól, nem hiába egy tizenéves fiú szemszögén keresztül látjuk a történetet." ${ }^{[17]}$ Hartung Attila hasonló korcsoportnak szánta alkotását, bár megszólításuk kapcsán már inkább pesszimista: „a film leginkább a 16 és 30 közöttieknek és a szülóknek tud szólni. Utóbbiaknak nem tudom, mennyi ideje van, a fiatalok pedig, egy szubkulturális réteget leszámítva, inkább a tutira mennek, beülnek mondjuk a Marvelfilmekre". ${ }^{[18]}$ A válogatásban szereplő filmek rendezôi között épp a legfiatalabbnak számító Hartung különösen fontosnak tartja a küldetéstudatos szerzői mozi komolyságát és a közönség attitûdjeinek megváltoztatását. E célból „készült egy segédanyag a filmhez; a fearofmissingout.hu weboldalon érhetô el, amelyet fốként tanároknak szántunk azért, hogy elvigyék az osztályokat a filmre, és utána beszélgessenek a témáról." ${ }^{[19]}$ A FOMO fiatalos hangvétele a múfajfilmes megoldásoknak köszönhetô. Ezek közül a magyar könnyúzenei kínálatból gazdagon válogató filmzene, az i-Phone kamerával felvett rövid videók és a karakterfejlődés sorvezetôjeként használt, diáknyelvben gazdag dialógusok a legfontosabbak. Az Akik maradtak tengerentúli fesztiválsikere nyomán, mely nagyban hozzájárult ahhoz, hogy Magyarország ezt a filmet jelölte az Oscar-díj legjobb külföldi film kategóriájában, Tóth Barnabás megtapasztalhatta a múfajfilmes és a múvészfilmes tudatosságot vegyítô szemléletmód életképességét. Szakmai továbblépése szempontjából is fontos támpontot jelent a hibrid forma: „Ha úgy érzem, olyan lehetôség adódik, 
amely esetben bele tudok tenni a filmbe bármit magamból és nem kizárólag technikai rendezőnek akarnak szerzôdtetni, akkor a múfaji határok sem érdekelnének. Azok a filmek érdekelnek, melyekben megvan az empátia lehetôsége, kapcsolatot tud teremteni vele a nézô.” [20]

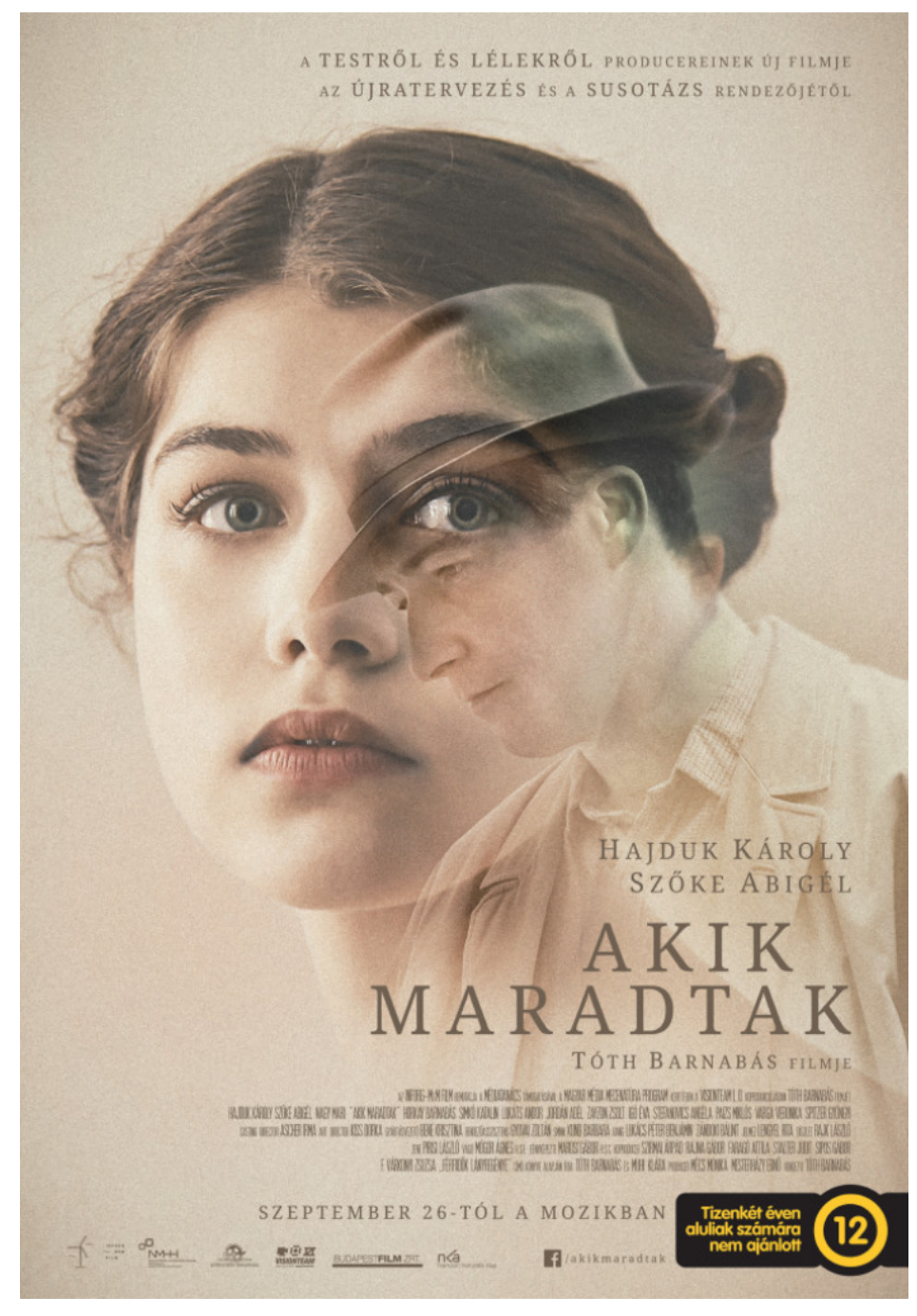

Az Akik maradtak (Tóth Barnabás, 2019) plakátja

A négy játékfilmes rendezô közül a legnagyobb tapasztalattal rendelkezô Szász Attila nem tartja magát szerzôi filmesnek, mert belátta, hogy forgatókönyvírói tehetsége gyérebb rendezôi képességeinél. Tóth Barnabáshoz hasonlóan ô is a film érzelmi hatás kiváltásának képességét emeli ki: „,[a]zt szeretném visszaadni a nézôknek, amit én is kaptam a filmtôl, tehát elsôsorban hatni szeretnék - fôleg érzelmi szinten, kevésbé intellektuálisan. Szerintem nem baj, ha elôbb primer szinten hat valami, és csak aztán gondol bele az ember mélyebben." ${ }^{[21]}$ A mélyebb belegondolás pontosan írja le a mozgást, amely az érzelmi hatásokat preferáló múfajfilmet a többletjelentések iránt elkötelezett múvészfilm irányába tolja. A rendezôt idézem: „[a]z emberek fôleg azért járnak ugyan moziba, hogy szórakozzanak, de jó lenne, ha maradna egy gondolat a fejükben, amin még morfondírozhatnak." [22]

Szász a közép-komoly múfajfilm nestigeni definíciójával összhangban a múfaji film stabil narratív szerkezetét alakítja úgy, hogy fajsúlyos társadalmi kommentárt fogalmazhasson meg. 
Véleményem szerint Hartung filmje is ezt a sémát követi. Tóth és Nagy alkotása a Virginás kínálta keveredést szemlélteti, azt tehát, amelyben a múvészfilmes beszédmód módosul, és befogadja a múfaji film elemeit. Nyilván nem ugyanahhoz a köztes állapotú filmfogalomhoz jutunk el a kétfajta módosulás eredményeként - nem ugyanazt az élményt nyújtja a múfajfilm, amely komolyságra tesz szert, mint a múvészfilm, amely élvezhetôbbé válik - jelen mondandóm szempontjából ezek a különbségek mégis másodlagosak. A beszédmódok hibriditása a kortárs magyar filmben tetten érhetô, és látszólag erôsödô tendenciaként érdekes.

A MEF egy olyan kis nemzeti filmkultúrába illeszkedô kezdeményezés, amelyben a szerzői és a népszerú, a múvészi és a szórakoztató alkotások között húzódó szigorú határok nemcsak a külsô, globális trendek hatására puhultak fel, hanem belülrôl, a hangját és közönségét keresô új generációnak köszönhetôen is. A hibrid beszédmód tudatosítása a kurzus során lehetôséget kínált a magaskultúrát a populáris kultúrával szembeállító értelmezôkeret meghaladására a négy játékfilm esetében, és arra ösztönzött, hogy ne a filmes forma iránti tudatosság alapján különböztessünk meg és hasonlítsunk össze rendezői stratégiákat, hanem az alapján, ahogy filmes témáikat relevánssá teszik a nemzetközi és hazai közönség számára. A következô részben a szemináriumokon felhasznált egyik fontos gondolatmenetet rekonstruálom, melynek segítségével a fesztiválrészvétel empirikus tényeire alapozva vitattuk meg a filmek témaválasztása és a globális filmes tendenciákhoz való csatlakozás sikere/sikertelenség között fennálló kapcsolatot.

\section{Az elszigeteltséget felfüggesztố kozmopolitizmus, a kozmopolitizmust gátló elszigeteltség}

A hat alkotás nemzetközi és hazai láthatóságát vizsgálva érdekes mintázat, gyakorlatilag két csoport rajzolható ki. Három film több fesztiválon is szerepelt, és bekerült a nemzetközi vérkeringésbe. Mind közül A létezés eufóriája a legsikeresebb, díjat nyert Locarnóban, Minszkben, Szarajevóban, Triesztben és Münchenben, Zágrábban, a Millennium Docs Against Gravity és a Choreoscope Nemzetközi Tánc filmfesztiválon, a legtöbb helyen közönségdíjban részesítették. Az Akik maradtak is számos nemzetközi fesztiválon szerepelt: Anchorage, Palms Springs, Szófia, Jeruzsálem, Antalya, Kairó, az európai film párizsi seregszemléje. Magyarországon a Jameson Cinefest és a Magyar Filmdíj közönsége láthatta. Több díjat is begyújtött, legtöbbet a Magyar Filmdíjon, de emellett elnyerte a Magyar Filmkritikusok Díját is. Az Apró mesék többek között a Balkan Panorama, az Avanca, a San Jose-i, a Pármai (filmzenei), a Love is Folly fesztiválokon, valamint a Magyar Filmdíjon részesült díjazásban, összesen tíz versenyprogramban szerepelt világszerte. Ez a három film nemzetközi láthatóságával és sikereivel kimagaslik a csoportból.

A FOMO-t, bár rendelkezik díjazással (Magyar Filmdíj - legjobb vágás), külföldi fesztiválok nem vetítették, a Szép csendben Tallinban volt versenyben, ahonnan díjazás nélkül távozott. A Csak családról ne esete egyedi: a rövid dokumentumfilmet [bár megnyerte a Budapesti Nemzetközi Dokumentumfilm Fesztivált [a nagyközönség televízióban láthatta, ezért megbízható 
közönségszámok sem állnak rendelkezésre. Bár statisztikák nem elérhetôek, A létezés eufóriája nemcsak külföldön, de itthon is közönségsiker volt, dokumentumfilmként meglepóen sok mozi vetítette, népszerúségi mutatói kiemelkednek a listán szerepló filmek közül. Hasonlóan adathiányos a helyzet az Akik maradtak esetében; itt is az online adatbázisok népszerúségi listáira támaszkodhatunk, ezekből kiindulva jelentős közönsége volt a filmnek. A Nemzeti Filmintézet adatbázisában három film esetében találunk a nézőszámra vonatkozó összesített statisztikát, ezek a következők: Szép csendben (9,633 fö), FOMO - Megosztod és uralkodsz (20,916 fö), Apró mesék (32,696 fô). Összességében elmondható, hogy két csoportot képeznek a filmek. A létezés eufóriája, az Akik maradtak és az Apró mesék külföldi és hazai kritikai elismerését a nézôszámok is alátámasztják. Érdekesség, hogy az utóbbi két film a 2020-as Magyar Filmdíjon egymással nagy versenyben volt: Tóth Barnabás inkább múvészfilmes értékekkel jeleskedô alkotása az összes fontos kategóriában (legjobb film, rendezô, forgatókönyv, férfi fôszereplő) felülmúlta Szász könnyebben emészthetô, inkább múfajfilmes kvalitásokat kidomborító munkáját. A második csoportból a FOMO felfelé kicsit kilóg, leginkább középerôsnek nevezhetô közönségstatisztikájával, de Kis és Nagy filmjeihez hasonlóan a nemzetközi színtérre nem sikerült betörnie.

Milyen következtetéseket vonhatunk le a fesztiválszereplés és a nézôszám alapján kialakított csoportosításból? Szembetúnô, hogy a felosztásban erôs tematikai hasonlóság érvényesül, az elsô csoport filmjei konkrét történelmi korszakot, a második világháború tragikus eseményeit és azok utótörténetét ábrázolják. A nemzeti és az európai emlékezet számára egyaránt traumatikus idôszak a magyar játék- és dokumentumfilm visszatérô témája, az egyik legerôsebb nemzetek feletti kapcsot jelenti Európában és a kontinens filmmúvészetében. A témában készült hazai alkotások kimondatlanul is kinyilvánítják a közös emlékezetpolitika iránti felelôsségüket, ahogy tették az utóbbi évek holokauszt tematikájú filmjei, élükön a Saul fiával (Nemes-Jeles László, 2015).

Nemes-Jeles filmjének sikere egyértelmú növekedést hozott a magyar zsidóság kálváriáját feldolgozó, ugyanakkor a túlélést hangsúlyozó filmek számában. Gárdos Péter Hajnali láz (2015), Török Ferenc 1945 (2017), Révész Bálint Nagyi projekt (2017) és Dobray György Kövek (2020) 【és maga az Akik maradtak is [a felívelés tartósságát jelzi. Tóth filmje szoros hasonlóságot mutat Gárdoséval: a táborok túlélóinek érzelmi törékenységét és a bizalomkeresését nagy pszichológiai érzékenységgel ábrázolják. Hasonlóan szoros kapcsolat áll fenn $A$ létezés eufóriája és a Nagyi projekt performatív stílusa között, mely elrugaszkodik „a múlt verbális feltárásának, archív anyagokból megkísérelt rekonstrukciójának, történetté/történelemmé formálásának késztetésétôl, és a megteremtett-kiprovokált szituációkon keresztül próbálnak hozzáférni a múlthoz." [23] További közös vonás a generációkon átívelô verbális és testi emlékezet, valamint a traumatikus múlt család(ias) közegben történő értelmezésének a kérdése.

Habár a fentebb említett összes alkotás részesült állami támogatásban, egyik sem tudhat be olyan elôkelô helyet a hivatalos nemzeti emlékezetpolitikában, mint a Sorstalanság (Koltai Lajos, 2005), Kertész Imre azonos címú regényének milliárdos költségvetésből forgatott filmes adaptációja. Koltai akadémiai stílusban fényképezett, ám meglehetôsen középszerú filmjéhez képest a Saul fia érdes stílusával és lekerekítetlen mondandójával válik korszakos múvé, a holokausztábrázolás 
egyetemes történetének megkerülhetetlen darabjává. Nemes-Jeles az ábrázolás határait feszegetô filmje, úgy tûnik, felszabadítóan hatott, és új korszakot nyitott a magyar film számára. A tragikus emlékezés kényszerének terhét a Saul fia mintegy saját vállára vette, így az elkövetkezô évek filmjei a holokauszt pokoli drámája helyett a fizikai és mentális gyógyulásra koncentrálhattak ( Hajnali láz és az Akik maradtak), a búntudat, tagadás, kollektív felelôsség kérdései felé fordulhattak ( 1945), az emlékmunka nem hivatalos, privát dimenzióit tárhatták fel (Nagyi projekt, A létezés eufóriája ). A filmes emlékezet eltávolodott a tragikus-epikus ábrázolásoktól, már nem a nagy, közös és ezért könnyen átpolitizálható emlékezet megteremtésén szorgoskodott: az áldozatiság kollektív teherként történó bemutatásáról a kisközösségi keretekben lehetôvé váló túlélésre helyezôdött a hangsúly.

A konkrét történelmi korszakban játszódó Apró mesék nem történelmi film: hiányzik belôle a monumentális történelemszemlélet, a múlt nemzetformáló erôként való ábrázolásának igénye, a történelmi alakok nemzeti hôsökként ábrázolása, mindaz tehát, ami miatt $A$ napfény ize (Szabó István, 1999), A Hídember (Bereményi Géza, 2002), A temetetlen halott (Mészáros Márta, 2004) vagy a Kincsem (Herendi Gábor, 2017) fontos filmek. Ha ez utóbbi korszakportrék és életrajzi filmek a történelmi események egyénre gyakorolt hatását vizsgálják, vagyis azt, ahogy az ember a történelem színpadává válik, Szász filmjeiben a történelmi kor jelenti az archetipikus emberi habitusok és örökérvényú magatartásmintázatok színpadát. Szász állandó forgatókönyvírójával, Köbli Norberttel közös filmjei - A berni követ (2014), a Félvilág (2015) és az Örök tél (2018) - a történelmi díszletek közé helyezett kisemberek egyetemes érvényességükben feltárulkozó jellemrajzai.

Tóth, Szász és Szabó filmjét a magyar történelem, társadalom és kultúra egyedi szövetéból az érdekli, amit ez a szövet a történelmi, társadalmi és kulturális tapasztalat egyetemességéból megmutatni képes, vagyis, ami a 20. századi nemzeti identitást szervezô toposzokat már mindig is az összeurópai, egyetemes tapasztalathoz kapcsolja. Az elszigeteltséget felfüggesztô kozmopolitizmus azoknak a filmeknek a sajátja, melyekben a helyi környezet és az ebben bukdácsoló hôsök még akkor is ismerôsnek tûnnek, ha az ábrázolt történelmi milió a külföldi nézô számára ismeretlen. A nemzeti történelemtól eloldott, annak beható ismeretét nem igénylő történelmi ábrázolások képesek sokféle kultúrájú közönséget megszólítani, azzal, ahogy a múltból a jelen számára használható tudásokat, a jellemrajzot és az emberismeretet hangsúlyozzák. 


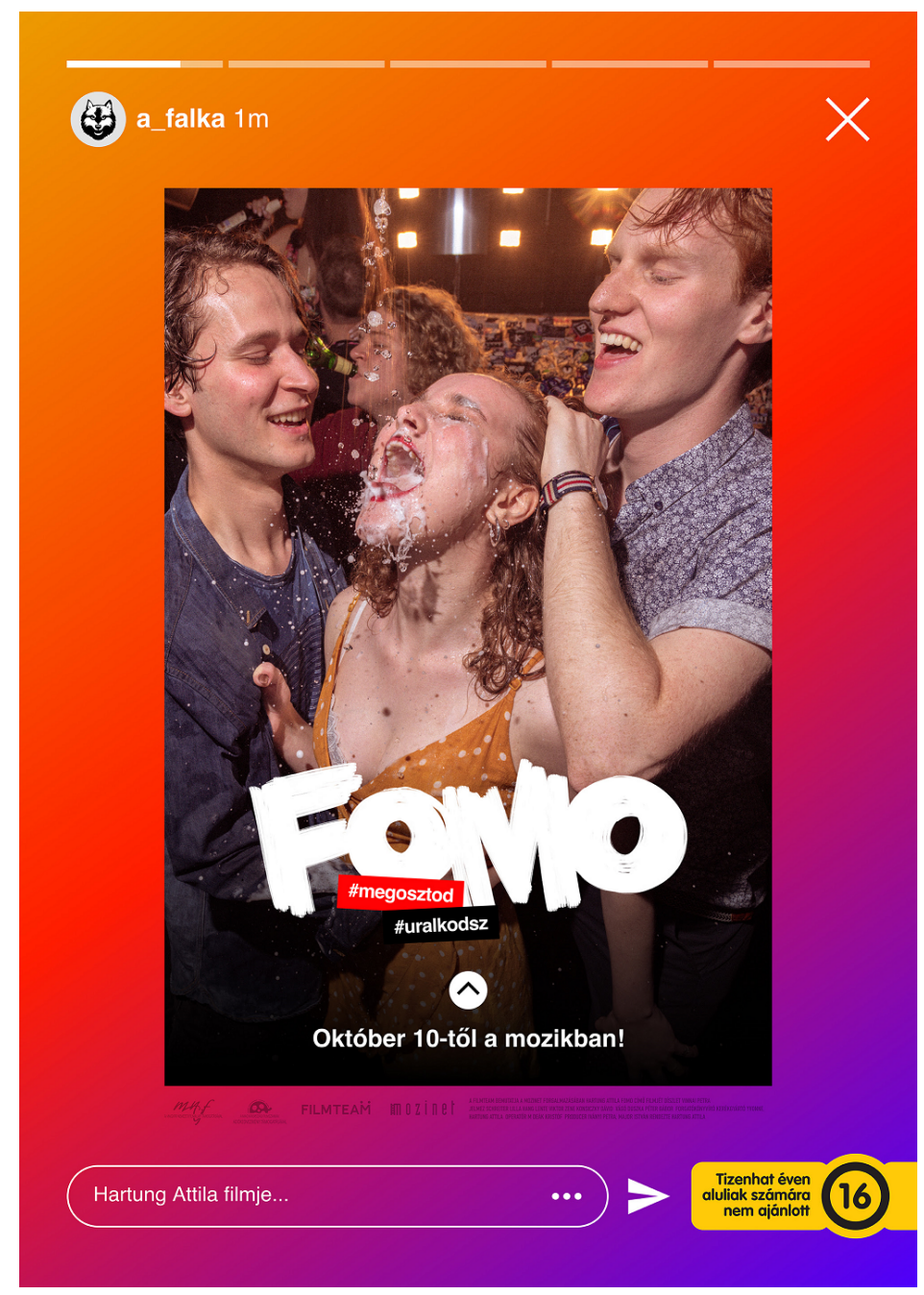

A FOMO (Hartung Attila, 2019) plakátja

A szerényebb fesztiválsikereket, nézettségi mutatókat és értékeléseket elérô három másik film napjainkban játszódó történeteinek közös tematikus fókuszában kamaszkorúak problémái, a FOMO és a Szép csendben esetében szexuális zaklatási ügy áll. A nôk szexista és patriarchális kiszolgáltatottsága elleni harcot zászlajára tûzô \#MeToo mozgalom teremtett aktualitást a két nyíltan kozmopolita orientációjú filmnek. A 2019-es év bôvelkedett a mozgalmat a filmkultúra felôl támogató alkotásokban. A sort még az elôzô évben vetített $A$ történet (The Tale. Jennifer Fox, 2018) kezdte, majd következett a Botrány (Bombshell. Jay Roach, 2019) és Az asszisztens (The Assistant. Kitty Green, 2019), de ebben az évben került képernyő́kre a Hihetetlen (Unbelievable. Lisa Cholodenko és Michael Dinner, 2019) címú minisorozat és került bemutatásra a Hatalmas kis hazugságok (Big Little Lies. Jean-Marc Vallée, 2017-2019) második és a The Morning Show (Mimi Leder és David Frankel, 2019-) elsô évadja. Ezekre a sztárszínésznôk egész hadát felvonultató produkciókra az európai mozinak nem volt igazán válasza, ami talán azzal magyarázható, hogy Hollywooddal ellentétben az öreg kontinens decentralizált finanszírozási struktúrájában nincsenek tejhatalmú pozíciók, és a döntéshozók körében a nemek is kiegyenlítetten képviseltetik magukat. [ ${ }^{24]}$ Míg európai film és társadalom e kérdésben mutatkozó konzervativizmusa megmagyarázhatja e téma mellôzöttségét, ${ }^{[25]}$ az angolszász érdeklôdés hiányát Nagy és Hartung filmje iránt már 
kevésbé. A visszafogott jegyeladások alapján a magyar közönség az európai mintát látszik követni, ami azért is érdekes, mert egyfelôl a tinédzserek közötti szexuális erôszak és mások online alázása a magyar film új társadalmi relevanciával bíró témája, másfelól a Schwechtje Mihály rendezte Remélem legközelebb sikerül meghalnod (2018) jó kritikákat és Netflixes terjesztést kapott annak ellenére, hogy állami támogatásban nem részesült.

A magyar \#MeToo filmek közös vonása a cselekmény iskolai környezetbe helyezése. Ekként a szexuális zaklatás kiskorú áldozatairól beszélnek, vagyis arról, amit vitán felül álló módon abúzusnak és erkölcstelen magatartásnak kell tekintenünk. Ezzel szemben az amerikai filmek és sorozatok a munkahelyi és családi zaklatásokat helyezik elótérbe, vagyis a búnösség és számon kérhetôség szürke zónáját. Késôbb részletesen is kifejtem véleményemet, miszerint a magyar filmek, bár nem vakok e szürke zóna iránt, nem tudnak vele mit kezdeni. A másik közös vonás a filmek rendezôjének neme. Míg a tengerentúli alkotások rendezôinek túlnyomó része nô, a magyaroké férfi. Miért? Vajon azért nem vállalkoznak nôi rendezôk a téma bemutatására, mert mesterségesen felfújt társadalmi problémának tarják az egészet, vagy mert a \#MeToo mozgalmat liberális maszlagnak tekintô, regnáló politikai és kulturális hatalom szemében elásnák magukat? A férfi rendezốk tehát a kiskorú lányokat tekintik a szexuális zaklatás szempontjából a legkiszolgáltatottabb csoportnak, az iskolát pedig az abúzusban fontos szerepet játszó intézménynek. Pszichologizáló-moralizáló ábrázolásmódjuk mindezt legitimálja: az iskola a szexuális öntudatra ébredés és különbözô értékrendek összeütközésének a helye, a deviancia melegágya, az a hely, ahol az összes társadalmi patológia leképeződik és gyökerezik. De az iskola az a hely is, ahol a globális kultúra - annak üressége vagy épp sokszínúsége - leginkább jelen van, ahol kapcsolatba kerül a lokálissal, a világtól elzárttal és elszigetelődóvel.

Az utóbbi évek európai mozijában az iskola visszatérô helyszín, a társadalmi patológiák ábrázolásának tere. Levan Akin És aztán táncoltunk (And Then We Danced, 2019), Thomas Vinterberg Még egy kört mindenkinek (Druk, 2020) és Maïmouna Doucouré Cukorfalatok (Mignonnes, 2020) címú filmje a patriarchális értékrendból fakadó homofóbia, a tanári alkoholizmus és kiégés problémáját, valamint a gyereklányok szexuális önképének közösségi média általi torzultságát egytôl-egyig iskolai környezetben vizsgálja. A szexuális zaklatáshoz hasonlóan ezek is korunk egyetemes problémái, mindazonáltal az egyes filmekben megjelenô társadalmi valóságból, ezek érzékeny ábrázolásából kerülnek kibontásra. Az univerzális jelleg a hitelesen megrajzolt lokális tapasztalatban gyökerezik. Az És aztán táncoltunk rendezôje a grúz néptáncot az intézményes és privát használat egymásnak feszüléseként, a nemzeti kultúra identitásrendje és a személyes identitás önkifejezési vágya közötti konfliktus színre viteleként ábrázolja, így tud hitelesen beszélni a homofóbiáról. Hasonlóképpen, a szorongást léttapasztalatként és társadalmi kohéziós erôként ábrázolva, az egyén állandó önkorlátozásra kényszerítettségét megmutatva tud Vinterberg a dán közösségi élet minden formájában jelen lévô, az emberi kapcsolatokat nagyban meghatározó alkoholfogyasztásról, a témát övezô társadalmi tabukat ignorálva, beszélni. Ennek a társadalmi látleletként felfogott lokális kontextusnak a 
keretében érthetjük meg a szereplók tetteit és motivációit. A Cukorfalatok egyetemes mondandóját is az afrikai bevándorlók európai értékrenddel gyakran kibékíthetetlen kulturális szokásai, egyáltalán a diaszporikus lét jelentette kitaszítottságélmény életszerú bemutatása teszi hitelessé. Bár ebben a filmben a Párizsban érvényesülni próbáló harmadik világ ábrázolása előszeretettel használ kliséket, a másik két alkotáshoz hasonlóan a moralizálástól mentes forgatókönyv, a modorosságoktól mentes szerepalakítások és a magas szintű technikai kivitelezés sok mindenért kárpótol. A Szép csendben és a FOMO ezekben az elemekben komoly kívánnivalót hagy maga után, és mindenekelôtt a szereplốk pszichológiai ábrázolására koncentrál. A probléma lokális társadalmi dimenziójának elmélyült megértésére inkább csak a helyi élettapasztalattal rendelkezô nézóknek van lehetôségük. Témafelvetésük kozmopolitizmusa és a globális értékválságra való reflexiójuk ellenére elszigeteltek: a pszichologizáló karakterábrázolás egydimenziós, a dramaturgia kiszámítható, a forgatókönyv túlírt, a szituációk túl színpadiasak. Mindezek a magyar múvészfilm nézôje számára nem ismeretlen típushibák, a tapasztalatlanság számlájára írhatóak.

\section{A trauma mint a filmek társadalmi kommentárjának közös nevezóje}

A filmek két jól elkülönülô csoportba sorolásakor két traumadiskurzust is megkülönböztethetünk. Elsôként a történeti traumákat középpontba állító filmekről beszélek. Szabó Réka filmjének kulcsfigurája Fahidi Éva, a kilencvenes éveiben járó holokauszt-túlélô, két memoár szerzője, aktivista és a Sóvirág címú táncelōadás egyik fôszereplôje. Az Auschwitz-Birkenau-i megsemmisító tábor egyik utolsó élô áldozataként, az elörehaladott kora ellenére szellemileg teljesen ép Fahidivel hagyományos beszélófejes dokumentumfilm is készülhetett volna. Szabó azonban az elôadás bemutatójáig vezetô próbák folyamatát rögzíti: rendhagyó werkfilmet forgat. A hagyományos interjúzás helyett Fahidi különbözô szituációkban emlékeket idéz fel és életfilozófiájáról mesél. Lényeglátóan fogalmaz, legyen szó akár a múltfeldolgozás beteljesíthetetlenségéról - „Soha nem jutsz a végére, ez a trauma, aminek nem lehet a végére jutni, és mindig ugyanarra a pontra jutsz... miközben boldogan élsz” -, akár a kimeríthetetlen életakarásról: „azt mindig tudni kellett, hogy nagyon jó dolog élni, hogy akármilyen szörnyúséges dolgok történnek meg, az ember alapjáraton él, és nagyon tudatosan él.” A film elődlegesen mégsem szavakkal, hanem testtel, megéléssel, mozgással ábrázolja a létezés traumája és eufóriája között feszülő dialektikus viszonyt.

A feldagadt visszeres láb, a hirtelen szédülések és a megroppant borda sem gyôzi le Fahidit: esendô testébe rendre új életet lehel, az öregedéssel dacolva megfiatalodik. A lét egyidejú beteljesíthetetlenségének és legyốzhetetlenségnek a színre vitele a film számára fontosabb, mint a túlélố történetéből készülố színpadi produkció dokumentálása. Szabó tudatosan használja a határidô-dramaturgiát ${ }^{[26]}$, azt a benyomást keltve mintha lenne jelentôsége annak, hogy az élete végéhez közeledố túlélô el tudja-e játszani önmagát szerepként. Valójában nincs, hiszen Fahidi a túlélố szerep kegyetlenségének tudatában élte le életét, a túlélốk búntudatával, kishúga elvesztésének elviselhetetlen terhével.

A körkörös, teljességében racionalizálatlan narratívájában Fahidi kishúga, édesapja, Magyarország 
és Auschwitz-Birkenau a fôszereplôk. A legkevésbé feldolgozhatatlan elemként, a múltbeli traumák felelôseként, a haláltáborban elpusztult apa, a naivitásának áldozatul esố családfố jelenik meg, aki a keresztény hitre való áttéréssel és vagyonával akarta megmenteni a családot. A táncelôadás kulcsjelenetében az apa viseli a vakságot és a halált szimbolizáló fekete jelmezt, az itt hallható monológ az ô szülőföld iránti vak bizalmát és folyamatos önhitegetését nevezi meg a családi tragédia forrásának: Fahidi szerint az egyre vadabb antiszemita rendelkezéseket foganatosító és állampolgárainak alapjogait lépésrôl lépésre felszámoló Horthy-korszakban az apának fel kellett volna ismernie, hogy a menekülés, az emigráció jelent egyedül megoldást. Családja vesztét az asszimiláció okozta, a társadalmi-kulturális normákhoz való igazodás, az átlagmagyarhoz való hasonulás kínálta illuzórikus biztonságérzet. A trauma előszobája a beteljesíthetetlen integráció. Fahidi dühös és szemrehányó monológjában Magyarország akként a helyként jelenik meg, ahol idôről idôre kiszolgáltatottá, üldözötté válnak azok, akik a közösségi értékeket és mintákat követik.

Az Akik maradtak két fôszereplôje, a középkorú Aladár és a kamaszkorú Klára, poszttraumatikus állapotban, a gyászmunka során kötnek barátságot. A forgatókönyvírásban is részt vállaló rendezô a trauma pszichopatológiája mellett a trauma élhetôvé tételének társadalmi korlátait is érti; ügyesen lavíroz a pótapa-pótlány melodramatikus narratívája és a romantikus cselekményszál között. Végül a barátság és nem a beteljesedett szerelem történeteként mesél a szereplôk pótolhatatlan, elfojthatatlan veszteségérôl. A film nem Aldó és Klára története, hanem a szülőföldre visszatért zsidóságé és mindazoké, akik maradtak: beleértve a hadiözvegyet és az árva testvérpárt, akikrôl nem tudjuk, hogy zsidók vagy nem zsidók. A gondoskodás testi gesztusaival és közösségi rítusaival, valamint a bizalom értékének a helyreállításával élhetôvé tett világ ugyanakkor ígéret marad. A sztálinizmusnak az emberek közötti bizalmat erodáló munkája korszakábrázolásként van jelen, de csak jelzésértékúen - párbeszédekben, a pesti bérház folyosójáról beszúrôdô ávós bakancsok dübögésében, a besúgó tanárnô karakterében -, ekképpen a magánélet terepére betolakodó államhatalom korszakoktól, sốt nemzetektôl független motívuma a filmnek. Mégis kevés olyan ország és korszak van, ahol ennyire koncentrált formában élték át az emberek, gyakran egyazon emberek, a kiszolgáltatottságot. A filmvégi jelenetben Klára talán ezért sem osztozik a többiek mámorában Sztálin halálhírérének bejelentésekor: az eufória a reménykeltô történelmi pillanat következménye és a nem a társadalmi szubjektum alaptapasztalata; lélegzetvételnyi haladék, mielôtt újra alámerül szorongásaiba. 


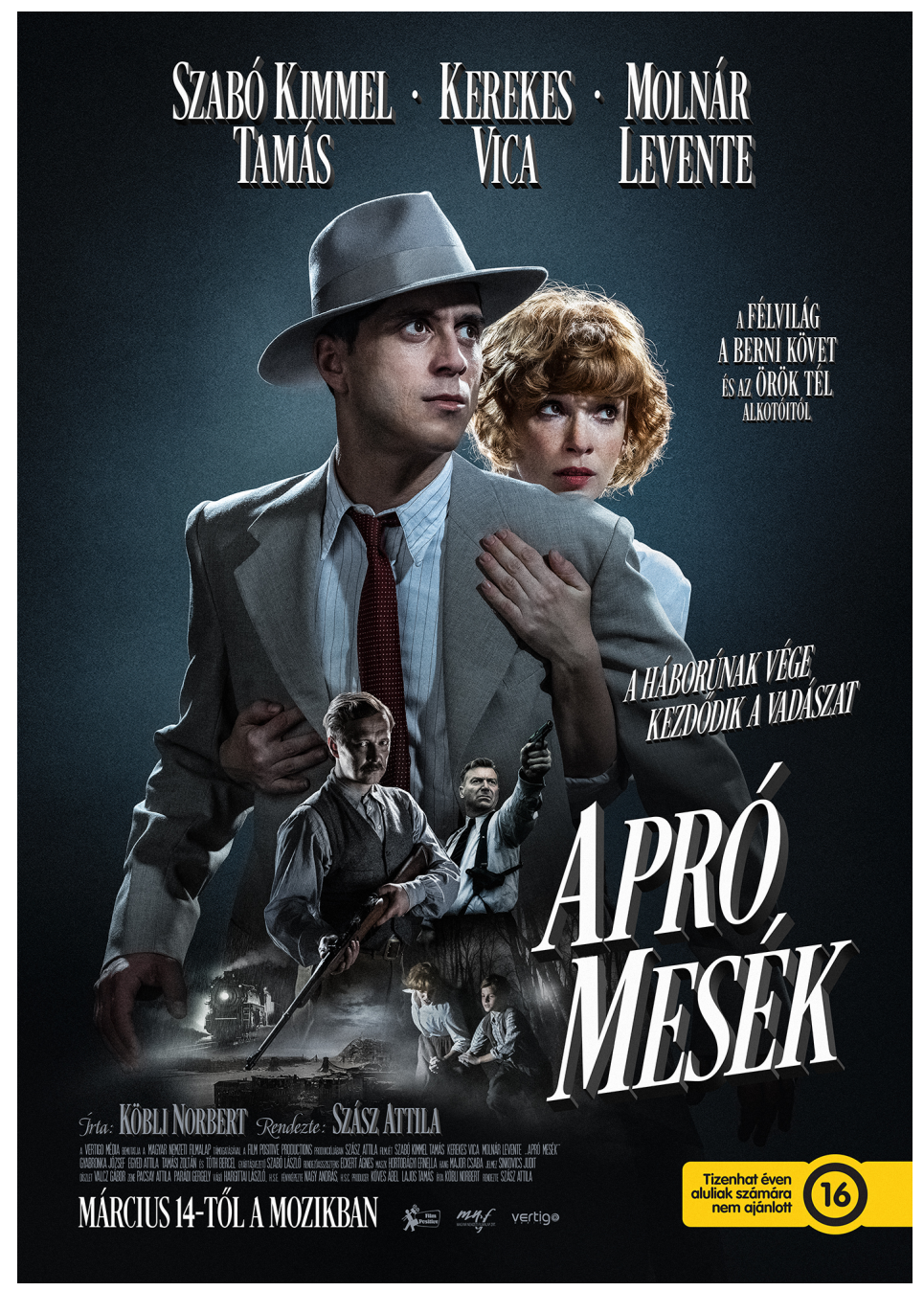

Apró mesék (Szász Attila, 2019)

Az eufórikus létezésnek az Apró mesékben személyes és társadalmi, egymásba fonódó korlátai vannak. A pszichológiai thriller múfaja a szorongó létezés ábrázolását az erkölcsi integritásukban megroppant, opportunista alakok köré szervezi. A pozitívként ábrázolt férfiszereplő, Hankó opportunizmusa jóságos és terapeutikus: a háborúban elveszettnek hitt katonák családtagjait keresi fel és bajtársuknak tettetve magát reménykeltô vagy éppen lezárást kínáló történetekben mesél utolsó találkozásukról. A férfi szélhámos, mégsem velejéig romlott jellem, mert, még ha katonaszökevény is, az átlagember számára értelmetlen háború elôl szökött el, és relatív jómódban élố embereknek hazudozik kosztért és kvártélyért. Más a helyzet Bércessel, a negatív vonásokkal felruházott férfiszereplôvel, aki saját valós történetét, fogolytáborban elkövetett kegyetlenségeit tartja titokban. Kegyes hazugságok helyett kegyetlenségét hazudja el, váratlan hazatérése után pedig folytatja kegyetlenkedését: fizikai és lelki terrort gyakorol családtagjai, elsôsorban az okos, szép és emancipált Judit felett. Erkölcsileg korrumpált, szadista jellemként Bérces az opportunizmust gyakorolja életvitelszerúen és nem a Hankó képviselte pragmatizmust. Az elôbbi szót ért bármilyen hatalommal, kiszolgál bárkit, aki hatalmat kínál számára mások felett. A film az autoriter ideológiákat (nácizmus, kommunizmus, patriarchátus) szolgáló hatalomittas alakot ábrázolja archetipikus gonoszként, akit nem lehet meggyốzni, csak legyôzni. Szász filmjében az 
ôsgonosz legyőzése nemcsak lehetséges, de szükséges is ahhoz, hogy új életet kezdjenek a szerelmesek. A szerelemi háromszögben feleslegessé váló harmadik elem, Bérces likvidálása nem opportunista cselekedet, mint James M. Cain A postás mindig kétszer csenget címú regényében, annak amerikai feldolgozásaiban és Fehér György Szenvedély (1998) címen leforgatott magyar adaptációjában. Itt a gyilkosság egyszerre elkerülhetetlen és ésszerú, nem egy pszichodráma eredôje, hanem a traumáktól megszabadulni képes lét feltétele. Az Apró mesék meseszerúen ábrázolja a traumát, mert kiegyenesíti annak körkörös szerkezetét, vagyis kijelöl egy végpontot, melyet a hősök maguk mögött hagyva új élet kezdhetnek.

A MEF-válogatásban szereplő Holokauszt-fókuszú alkotások nem használnak archív felvételeket, illusztrációkat, rekreált emlékjeleneteket. Szász filmjében a verbalizálás felól a megmutatás felé tolódik el a hangsúly, a konfliktusokat a maguk fizikalitásában ábrázolja a film. A kortárs történetekben a megmutatás igénye felerôsödik. Bár nem azonos mértékben és nyersességgel, de a két szexuális zaklatással és erôszakkal foglalkozó filmben a trauma kézzelfoghatóbb. A Szép csendben esete különösen érdekes, mert a zenekarvezetô Frigyes és kiskorú tanítványa, Nóri fizikai kapcsolata nem erôszakos. A film az idôsödô férfit nem szexuális ragadózóként ábrázolja, közeledése nem agresszív, a gyengéd érintések a hangszer helyes tartását segítô instrukcióknak tûnnek. Kezdetben a tehetséges elsóhegedús Dávid sem tulajdonít nagy jelentôséget Nóri narratívájának, bizonyítékot követel, és végül egy hangfelvétel győzi meg arról, hogy istenített mestere, szinte pótapja erkölcstelenséget követett el. A fiúhoz hasonlóan a nézô sem kap perdöntő bizonyítékot az abúzusról, a film a karizmatikus jellem és viszonzatlan szexuális vonzódás, a bizalom és a naivitás, a rokon lelkek összetartozás-érzése és a megtévesztettség érzése közötti vékony határra, az emberi kapcsolatok félreértelmezhetôségére helyezi a hangsúlyt. Az eldönthetetlenség szürke zónája, az érzések megbízhatatlansága, a tettek és szavak jelentésének labilitása, végsô soron pedig az én-narratíva megrepedezése a traumatikus. A filmben megjelenô pszichés dinamikából arra következtethetünk, hogy Nóri számára a Frigyes közelében tapasztalt kiszolgáltatottság-érzés bár kényelmetlen, de traumatikussá saját ítélóképessége iránti elbizonytalanodása válik. A lány önmagával kerül ellentmondásba: mást mond teste és a felnôtt világ tiszteletére nevelt, hovatovább annak öntörvényúsége iránt vonzódást is érzô intellektusa. De a környezetével is konfrontálódik, mindazokkal, akik számára kényelmetlen egy labilis kamaszlány szavai alapján elítélni a felnôttek világát. Egyetértek Kovács Bálinttal, aki szerint fontos diagnózist állít fel a film, megmutatva „hogy a bennünket is körülvevô társadalomba milyen mélyen be van épülve ez a tagadás vagy zsigeri elutasítás [...] hogy hogyan megy el mellettünk szép csendben mindaz, ami szép csendben örökre tönkreteszi valaki más életét”. ${ }^{[27]} \mathrm{A}$ rendezô éleslátására vall, hogy a paternalizmus csendes múködésérôl azoknak az intelligens, szorgalmas és ambiciózus diákoknak a körében kínál látleletet, akik éppenséggel intelligenciájuk, szorgalmuk és ambiciózusságuk okán válnak a paternalizmus csendes kiszolgálóivá. Fontos lett volna azonban azt is hangsúlyozni, hogy a paternalizmus nem csak generációs problémaként van jelen Magyarországon, hanem (még mindig, változatlanul) az emberi kapcsolatok teljes skáláját szervezô szociálpszichológiai dinamikaként. Hatalmában megroppantani kétségtelenül az egymásért kiállni hajlandó, empatikus tagokból álló kisközösségekben lehet, ahogy azt a filmben is 
láttuk. Mégis szerencsésebb lett volna, ha a Nóra iránt valószínúleg romantikus érzelmeket tápláló, így érdekmentesnek nem mondható Dávid helyett egy nôi karakter nyújt támaszt a lánynak. Így a néző felé nem az lenne sugallva, hogy a gyenge és magatehetetlen lány problémáit mindenképp a fiúnak kell megoldani, aki persze erre képtelen, hisz a film Dávid tehetetlenségérôl, morális vergôdésérôl szól.

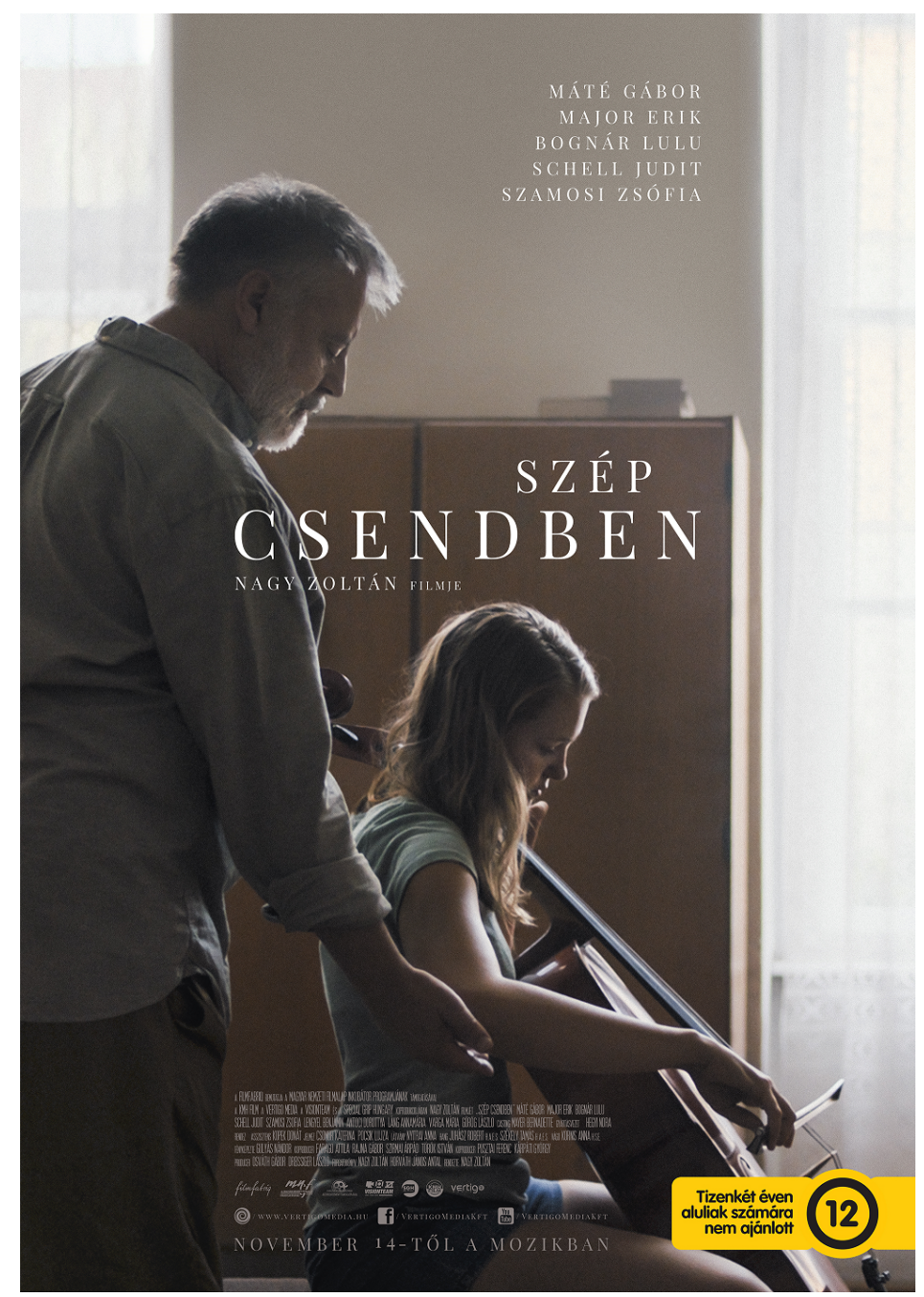

A Szép csendben (Nagy Zoltán, 2019) plakátja 
A Szép csendben a múvészfilmeket idéző visszafogott stílusban és a traumák létrejöttében alapvetô szerepet játszó szürke zónára fektetett hangsúllyal intellektuálisabb élményt kínál, mint a harsány, a szexuális erôszakot nyíltan ábrázoló FOMO. Hartung filmjének exhibicionista vizuális stílusa összhangban van a YouTube-videókkal, melyeket az egymás szivatásában jeleskedô, az online trash-kultúra berkeiben érvényesülni vágyó fốszereplôk készítenek. Szöges ellentétben Nagy filmjének a klasszikus zene elitkultúrájával azonosuló, tisztelettudó mintafiataljaival, a négy srác toxikus maszkulin szerepeket bálványozó, a hagyományos erkölcsi értékek határait feszegetô vagy azokat egyenest áthágó viselkedése a képfogyasztás körül szerveződô tömegkultúráról kínál képet. Mindenekeloott a prank videók ellenszenvességükben élvezetes, a kamaszkori iránytalanságot, apátiát dicsôítô múfajáról, melyek készítői, az önkifejezés e formájának ellentmondásosságát szemléltetve, a társadalmi tabuk áthágásával kívánnak társadalmi elfogadást elérni.

A férfiközpontú Youtuber-szubkultúra válik a nemi erôszak színpadává, miután a fiúcsapat egyik tagja, a társai elôtt vagányságát bizonyítani akaró Gergô, egy házibulin rámászik részegségtôl öntudatlan osztálytársára, és telefonjával felvételt készít a beleegyezés nélküli szexuális aktusról. Ez már nem csínytevés, hanem törvényes búntett, egy másik ember méltóságának lerombolása. A film hátralévő részében Gergô fokozatos elôbújását mutatja be az online tér kínálta anonimitásból, vezeklését a budapesti éjszakában.

Hartung az erkölcsi értelemben vett felnôttté válás múfaji sémájában, vagyis egy leegyszerúsítô és didaktikus elbeszélókeretben egyesíti a gátlástalan közösségi média és a nemi erôszak egyaránt személyiségromboló témáját. Azzal viszont, ahogy a megalázott lány traumája helyett a fiú búnbánatát állítja középpontba, arányt téveszt, sốt aláaknázza a hegemón maszkulinitás kritikájának saját maga számára kitúzött célját. A trauma kirekesztô diskurzusát gyakorolja, amennyiben számúzi az áldozat narratíváját, a nô nézôpontját. Miért vagyunk megfosztva Lilla kiszolgáltatottságának, elkeseredésének, dühének ábrázolásától, az igazi trauma megmutatásától? Mennyiben tekinthetjük hitelesnek Gergó kilépését a nárcisztikus és felelôsségtudat nélküli Falkából, vagy éppenséggel a hatalmaskodó és egoista apafigura ártalmas befolyása alól, ha a film maga is paternalista uralmat gyakorol nézôje felett? 


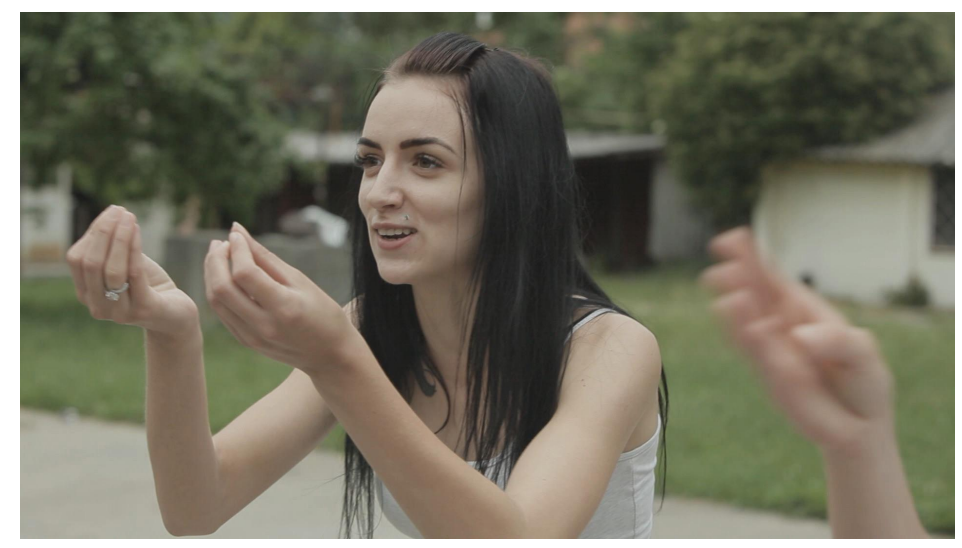

Jelenet a Csak családról ne (Kis Anna, 2019) címú

dokumentumfilmból

A fơvárosi elitgimnázium közege fényévekre van az életszínvonalban és életminôségben folyamatos lemorzsolódással küzdô békési település szakmunkásképzô intézetének világától, Kis Anna Csak a családról ne címú filmjének helyszínétôl. A film részben kiégett pedagógusok és 15-20 év közötti, halmozottan hátrányos helyzetú diákok motivációs és önismereti tréningjén készült. Nem sok mindenrôl beszélnek szívesen, de a családról semmi esetre sem. A cím precízen adja vissza a személyes témák megvitatásának elutasítottságát: a magánélet megmutathatatlanságában válik a dokumentfilm szociografikus témájává a tabusított, traumákkal teli gyerekkor. A film nem beszél külön szexuális kizsákmányolásról, elejtett megjegyzésekból mégis kiderül, hogy az egyik kamaszlány Svájcban szexmunkásként dolgozott. A témát övezô hallgatásból következtethetünk a prostitúció közösségben való erôs jelenlétére és a családok széthullásában játszott központi szerepére. A \#MeToo mozgalom eszményei ebben a marginalizált környezetben megvalósíthatatlanok. Míg a titkaikat nyilvánosság elé táró elsô világbeli nôk számára az elhallgatás lealacsonyító és elhibázott, a társadalmak perifériáján, a világ szegénynegyedeiben lakók számára alapvetố túlélési stratégia. A némaság a szégyent hivatott elfojtani, nem az elbliccelt órák, a Svájcban eltöltött hónapok, a családon belüli erôszak esetleg más hasonlóan komoly búncselekmények elkövetése miatt érzett szégyent, hanem a gyerekkor hiánya miatt érzett szégyent. Mintha tehetnének bármirôl is, és nekik kéne szégyellniük magukat a traumákban leélt gyerekkor, a kiszolgáltatottság és reménytelenség miatt, amelyrôl egy-egy elejtett mondatból alkothatunk képet. Nagyon fontos, hogy ezeket a mondatokat nem a kamerának, hanem tanáraiknak mondják, azoknak az embereknek, akiket szociális munkásként, pszichológusként és mindezek elôtt pótszülőkként ábrázolja a film. Olyan emberekként, akik türelmet, idôt, bizalmat, születésnapi ajándékot és gömbfagylaltot adnak diákjaiknak, azt, amit a családba soha nem kaptak meg, azt, ami a szégyenérzetet szublimálni képes. Az eufórikus ellentettjét, a szégyenteljes létezést egyéni elfojtás eredményezi, az viszont már a torz társadalmi értékrend következménye, hogy a traumák hordozói gyengének, vesztesnek és kitaszítottnak látják magukat. A gyengeség kiváltotta félelem a szégyenérzet, nem csoda, ha a beilleszkedés korlátjának tekintett traumatikus élettapasztalatokat a fiatalok Én-narratívája elsüllyeszti, kirekeszti. Minél inkább személyiséghibának tartja a közösség a traumákat, vagyis alkot téves képet a traumatizáltság pszichés mechanizmusáról, annál nagyobb a társadalmi értékrend szerepe az elhallgató, elfojtó 
magatartásformák kialakulásában. A Csak családról ne némasága torz értékrenden alapuló társadalmi normakövetésból fakadó, a szégyen kultúráját megalapozó patológia.

A traumatizált személyiség a hat versenyfilm közös tematikus motívuma, a trauma közösségi és társadalmi vetületét mégis más módon viszik színre. A két dokumentumfilm közös nevezôje az a felismerés, hogy a traumák okozta válsághelyzeteket tudássá formálva, kimondva és Énnarratívába integrálva lehet kezelni. De a párhuzamok itt nem állnak meg: mindkét alkotás a társadalmi normáknak történô megfelelési vágyból eredezteti a traumát. Fahidi édesapja a normáknak való megfelelés ellenére, Kis filmjének fiataljai a normáknak való megfelelés lehetetlensége miatt kerülnek marginalizált, traumatikus élethelyzetekbe Magyarországon. A kozmopolita-polgári miliố és a vidéki Magyarország hátrányos helyzetú települése között lévô jelentôs társadalmi különbségek ellenére azt érezzük, hogy ugyanabban a társadalmi térben, ugyanabban a problémahalmazban vagyunk. A létezés eufóriája a tánc absztrakt nyelvén viszi színre a traumákat, amit a Csak családról ne a nyelv elvesztésének nem kevésbé univerzális tapasztalatával, a kiszolgáltatottak némaságával érzékeltet. Mindkét esetben a dokumentumfilm ágenciateremtô potenciálja a fontos, de míg ott az önkifejezés képessége adott, itt az akkut társadalmi probléma megértése a feladat. A nemzetközi és hazai színtéren legkevésbé látható Csak családról ne pontosan azért tûnik a leginkább jelenbeli alkotásnak, mert arról beszél, amirôl nehéz beszélni, és amirôl nem is akarunk beszélni. Filmformailag és problémalátásban $A$ létezés eufóriája állítható leginkább párhuzamba vele, mert a traumák kibeszélésének nehézségeit bár történetileg, de a társadalmi mentalitásokkal összefüggésben ábrázolja.

\section{Összegzés}

Tanulmányom megírása után, 2021. október végén került sor a MEF nyertes filmjét kiválasztó hallgatói workshopra. ${ }^{[28]}$ Az élénk vitákban gazdag kétnapos rendezvény meghatározó módszertanát a párba állított filmek (A létezés eufóriája/Csak családról ne, FOMO/Szép csendben, Akik maradtak/Apró mesék) összehasonlítása, ezzel szoros összefüggésben pedig az összehasonlíthatóság kereteinek a kialakítása jelentette. A beszélgetések során többször megjelentek a jelen szövegben általam fontosnak tartott múfaji kérdések, illetve a nemzetközi trendek filmekre gyakorolt hatása, a legkiélezettebb nézetkülönbségek mégis a kortárs témájú problémafilmek, mindenekelôtt a FOMO kapcsán alakultak ki. Saját kurzusom tapasztalataihoz hasonlóan a vita túlmutatott a szorosan értelmezett filmtudományi kérdéseken és az említett film kapcsán felszínre hozta a generációkon átívelô értékválsággal és a káros társadalmi attitûdökkel való szembenézés fájdalmas realitását. Ezt se akkor, se most nem tartottam felesleges körítésnek, épp ellenkezőleg, úgy gondolom, hogy ez teszi a filmet az élô kultúra részévé és szolgálja leginkább a gondolati pluralitás és vitakultúra fejlesztésének pedagógiai küldetését.

Mindannyiunk meglepetésére Kis Anna Csak családról ne címú filmje nyerte a MEF 2019-es kiírását. A meglepetést nem az jelentette, hogy egy televíziós és online terjesztésben forgó, a filmkritikusok figyelmét javarészt elkerülô alkotás és a szélesebb közönség számára kevésbé ismert 
rendezó nyert, hanem hogy egy dokumentumfilm végzett az elsô helyen. Ráadásul egy olyan dokumentumfilm, amely nem korábbról ismeretlen koncepciót, formabontó filmnyelvi megoldásokat használ, hanem a részvételi filmezés - a hetvenes évek Balázs Béla Stúdiós dokumentumfilmek óta népszerúségnek örvendô - technikáját és etikáját. A Csak családról ne témaérzékenységét tekintve sem nevezhetô forradalminak: a BBS múhelyben elkészült Nevelésügyi sorozat (1973), Schiffer Pál roma tematikájú dokumentumfilmjei és más rendezôk filmszociográfiái a vidéki Magyarország problémáit Kis filmjéhez hasonló érzékenységgel tárták fel. E formanyelv és témafelvetés jelenkori relevanciája mellett kiálló szakmai elismerés nem a dokumentumfilm fejlôdésképtelenségérôl beszél, hanem arról, hogy Magyarország egyes részein megállt az idô. És, hogy errôl beszélni kell. Amikor a felsőoktatás krémjéhez tartozó, nagyvárosokban lakó egyetemi hallgatók a kisvárosi szakiskola bukdácsoló, túlkoros és mélyszegénység árnyékában élő diákjaival a filmnek köszönhetôen megélnek egy találkozást, ezzel nem csak filmtudományos látókörük szélesítik, nem csupán a filmes kifejezés aktuális problémáit értik meg, de a filmértést a társadalmi, kulturális és pszichológiai megértés felé is kiterjesztik. Az idei és az eljövendô diákzsûrik döntése egyfelól sorozatos viták és intenzív pedagógiai munka eredménye, ugyanakkor maga is megfogalmaz egy pedagógiai üzenetet: a díjazással a hallgatók azt mondják generációjuk tagjainak és a tágabb közönségnek, hogy ezt a filmet érdemes megnézni, mert relevanciával bír jelenünkre, és olyan kérdéseket fogalmaz meg, melyeket a mindennapokban egymásnak és magunknak is felteszünk.

Tanulmányom a Magyar Egyetemi Filmdijj, egy független, filmes tanulmányokat végző egyetemi hallgatókat célzó kezdeményezés elôzményeit, lebonyolításának keretét, célkitǔzéseit és eredményeit vizsgálta. Saját tapasztalatok alapján tettem kísérletet annak bemutatására, hogy a filmdíj általános pedagógiai küldetése milyen konkrét formában valósult meg a hat kiválasztott film feldolgozása során. Értelmezésemben a tanórai megbeszélés és vita feladata az általános szempontok konkretizálása, az alkotások összehasonlítását biztosító keretek kidolgozása. A 2019-es hosszúlista tanúsága szerint a több film (jelen esetben a játékfilmek) összehasonlíthatóságát biztosító keretek a magyar filmkultúra átfogó tendenciáit teszik olvashatóvá, úgymint a „középkomoly múfajfilm" hibrid filmforma elôretörését. Az alkotások csoportosításával specifikusabb keretek jelölhetóek ki, a tanulmány ezt a magyar mint kis nemzeti filmkultúra és az európai/globális tendenciák egymásra hatásának elemzésével kívánta szemléltetni. A legizgalmasabb feladatot azoknak az összehasonlító kereteknek a megkonstruálása jelenti, amelyek különbözô múfajú játékfilmekben és dokumentumfilmekben tesznek olvashatóvá közös motívumokat és problématudatosságot. Jelen esetben ezt a minden filmben visszatérô, homogenizáló elemet a traumatapasztalat ábrázolása jelentette. A traumatikus élmények filmekbe emelésének mikéntje és miértje, a lelki és testi abúzusok érzéki, érzelmi és intellektuális reflexió tárgyává tétele különbözô stratégiákat körvonalaz a filmekben. Ezeket a stratégiákat vizsgáltam a hat alkotás részletesebb elemzésekor; különbségeiknek és hasonlóságaiknak a feltérképezésével a trauma társadalmi képzeteit, a jelenünkrôl való gondolkodásban játszott szerepét kívántam körvonalazni. Számomra nyilvánvalóvá vált, hogy az elkövetkezô évek MEF foglalkozásai akkor 
tudják pedagógia potenciáljukat leginkább megvalósítani, ha a filmtudományi problémák megértése mellett a társadalmi jelenségek kritikai megközelítését is elôsegítik.

\section{Jegyzetek}

1. Jelen tanulmány a Magyar Tudományos Akadémia Bolyai János Kutatási Ösztöndíja, valamint a Nemzeti Kiválóság Program (ÚNKP-21-5) ösztöndíjának támogatásával készült.

2. „In times of growing nationalism in Europe and elsewhere we had the idea to look for a common element to foster a European understanding, to search for a common European identity defined by culture, especially by film.” (European University Film Award: About Us. URL: https://www.eufa.org/about/)

3. A MEF független filmdíj, ugyanakkor szoros intézményi kapcsolatot ápol a Magyar Filmtudományi Társaság egyesületi formában múködô szakmai szervezetével, melynek tagjai kulcsszerepet vállalnak a lebonyolításban. A Társaság éves konferenciáján, az ôszi szemeszterben történik a díjátadás.

4. ,articulating values and ideas, searching for a way to understand this world and each other and overcoming national, social and stereotype marks." (European University Film Award: 2nd European University Film Award 2017. URL: https://www.eufa.org/recap/2nd-european-university-film-award-2017/

5. A magyar diákok filmes preferenciáinak életkori sajátságairól és a filmválasztást befolyásoló kritériumokról lásd Hartai László friss kutatását. (Hartai László: A zék, az alfák és a filmoktatás. Apertúra, 2018. tél. URL: https://www.apertura.hu/2018/tel/hartai-a-zek-az-alfak-es-a-filmoktatas/)

6. Hartai László: i.m.

7. Pócsik Andrea: Európaiság a (kritikai) filmoktatásban. In Europe and European Cinema at Times of Change. Szerk. Zsolt Győri és György Kalmár. Debrecen, Debrecen University Press, 2021. 44.

8. Magyar Filmtudományi Társaság honlapján: Magyar Egyetemi Filmdíj. URL: https://www.filmtudomanyitarsasag.hu/oktatas/magyar-egyetemi-filmdij/

9. Pócsik Andrea: Playing a Film Festival Jury: Cooperative Competition in the Classroom. Alphaville: Journal of Film and Screen Media, 2017. tél (14). 204. URL: www.alphavillejournal.com/Issuel4/Dossier.pdf

10. A „Romakép Múhely” 2011-tôl múködô filmklub, melynek keretein belül a magyarországi és nemzetközi roma közösségek életét, problémáit bemutató dokumentumfilmek kerülnek vetítésre és megvitatásra meghívott szakértôk részvételével és diákok moderálásával. A kisebbségi közösséget érintô kérdéseket és azok filmes reprezentációját kritikai elméletek mentén feldolgozó beszélgetések nagy hangsúlyt helyeznek a társadalmi érzékenyítésre és a médiatudatosságra nevelésre.

11. Hjort, Mette - Duncan Petrie: Introduction. In The Cinema of Small Nations. Szerk. Mette Hjort és Duncan Petrie. Edinburgh, Edinburgh University Press, 2007. 2-7.

12. Uo. 9.

13. A bérmunkák pozitiv megítélése persze nem egységes, például a statiszták bére évek óta változatlan, a kifizetések csúsznak és feketén történnek, a közvetítôi dijjak magasak, a munkakörülmények pedig közel sem mondhatóak ideálisnak

14. Nestingen, Andrew: Crime and Fantasy in Scandinavia. Fiction, Film, and Social Change. Seattle, Washington University Press, 2008. 73.

15. A fogalomnak tudomásom szerint nincs hivatalos magyaritása, de elképzelhetôek jobb fordításai, akár a középszintû́ látványmozi vagy a középszintú mưfajfim. Míg e két utóbbi verzió a medium-concept terminust kívánja minél húségesebben fordítani, az általam választott kifejezés is a high-concept (magasröptû́) és a low-concept (primitív, középszerû) közötti jelentésmezốre koncentrál, de ezt a 
köztességet nyelvileg máshogy, inkább értékjelzóként nevesíti. A nestingeni terminus fordításának nehézségeiben olyan, a fordítás szempontjából hasonlóan problémás fogalmak köszönnek vissza, mint a middlebrow cinema, melyet félkönnyed filmnek fordítanék, mégpedig azért, mert ez a kifejezés is értékítéletet megfogalmazó köztes állapotot jelöl (a lowbrow és a highbrow keveredését). A midcult film sem könnyú eset, talán ezért is tartotta meg a filmes szakma az eredeti kifejezést, akárcsak ellentétpárját (mass cult).

16. Virginás Andrea: Film Genres in Hungarian and Romanian Cinema. History, Theory, and Reception. Lanham, Lexington Books, 2021. 297.

17. Incze Kata: „Amit nem látunk, az nem történik meg.” Beszélgetés Nagy Zoltánnal, a Szép csendben rendezőjével. Filmtett, 2019. november 15. URL: https://www.filmtett.ro/cikk/amit-nem-latunk-az-nemtortenik-meg-nagy-zoltan-szep-csendben-interju/

18. Szántó Eszter: Hartung Attila: Komoly lelkiismeret-furdalása volt a szereplóknek a forgatáson. 24.hu, 2019. november 5. URL: https://24.hu/kultura/2019/10/05/hartung-attila-fomo-film-z-generacio-interju/\#

19. Csizmadia Attila: Félünk, hogy kimaradunk? - interjú Hartung Attilával, a FOMO rendezójével. Socfest, 2019. október 8. URL: https://socfest.hu/film/felunk-hogy-kimaradunk-interju-hartung-attilaval-a-fomorendezojevel/

20. Csákvári Géza: Jó most magyar rendezônek lenni - interjú Tóth Barnabással. Népszava, 2020. január 11.URL: https://nepszava.hu/3063146_jo-most-magyar-rendezonek-lenni-interju-toth-barnabassal

21. Gyárfás Dorka: „Azt szeretném visszaadni a nézóknek, amit én is kaptam a filmtől” - interjú Szász Attila rendezóvel. wmn.hu, 2019. november 10. URL: https://wmn.hu/kult/50401-azt-szeretnem-visszaadni-anezoknek-amit-en-is-kaptam-a-filmtol-interju-szasz-attila-rendezovel

22. Uo.

23. Stôhr Lóránt: Személyesség, jelenlét, narrativitás. Budapest, Gondolat, 2019. 210-211.

24. Roxborough, Scott - Rhonda Richford: Europe's Bitter \#MeToo Debate: Bardot, Bertolucci and the „Threat of Change”. The Hollywood Reporter, 2018. május 3. URL: https://www.hollywoodreporter.com/movies/movie-features/europes-bitter-metoo-debate-bardotbertolucci-threat-change-1107198/ A szerzôpáros egy további lehetséges okra is rámutat. Érvelésükben az európai mozi szerzói kultusza olyan helyzetet teremtett, melyben a rendezó szakmai integritása fontosabb a személy morális integritásánál. Ebból következóen „kiszámíthatatlan eredménnyel zárulhat a vita, amelyet az Egyesült Államokban az azonnal változásokat követelő Time’s Up és \#MeToo mozgalom uralt”.

25. Charlène Favier Slalom (2020) címú elsô játékfilmje ugyancsak egy kamaszlány szexuális kiszolgáltatottságáról szól, és bár több fesztiválon is jól szerepelt, és az EUFA rövid listájára is felkerült, jegyeladások tekintetében nem teljesített jól.

26. A tudatos feszültségkeltést Soós Tamás is kiemeli kritikájában: „vajon meg tudja tanulni a premierre saját, ezerszer elmondott mondatait a fôszereplő, amit most légiesre sûrített monológként kéne előadnia?” (Soós Tamás: Élet, öröm, Auschwitz: A létezés eufóriája. Revizor, 2019. szeptember 11. URL: https://revizoronline.com/hu/cikk/8048/a-letezes-euforiaja/)

27. Kovács Bálint: De ugye nem nyúlt a testedhez úgy a tanárod? Kritika a Szép csendben címú filmrôl. Index, 2019. november 19. URL: https://index.hu/kultur/cinematrix/2019/11/19/szep_csendben_kritika_szexualis_zaklatas_metoo_magyar_film_nagy_zolta 
28. A Budapesti Metropolitan Egyetem biztosított helyet október 29-30-án a Pörczi Zsuzsanna szervezésében megtartott rendezvénynek, melyen nyolc egyetem hallgatói képviselói és a kurzusokat/filmklubokat vezetô oktatatók vettek részt.

\section{Irodalomjegyzék}

- Csákvári Géza: Jó most magyar rendezőnek lenni - interjú Tóth Barnabással. Népszava, 2020. január 11. URL: https://nepszava.hu/3063146_jo-most-magyar-rendezonek-lenni-interju-tothbarnabassal

- Csizmadia Attila: Félünk, hogy kimaradunk? - interjú Hartung Attilával, a FOMO rendezójével. Socfest, 2019. október 8. URL: https://socfest.hu/film/felunk-hogy-kimaradunkinterju-hartung-attilaval-a-fomo-rendezojevel/

- European University Film Award: 2nd European University Film Award 2017. URL: https://www.eufa.org/recap/2nd-european-university-film-award-2017/

- European University Film Award. „About Us”. URL: https://www.eufa.org/about/

- Gyárfás Dorka: „Azt szeretném visszaadni a nézóknek, amit én is kaptam a filmtôl” - interjú Szász Attila rendezővel. wmn.hu, 2019. március 10. URL: https://wmn.hu/kult/50401-aztszeretnem-visszaadni-a-nezoknek-amit-en-is-kaptam-a-filmtol---interju-szasz-attilarendezovel

- Hartai László: A zék, az alfák és a filmoktatás. Apertúra, 2018. tél. URL: https://www.apertura.hu/2018/tel/hartai-a-zek-az-alfak-es-a-filmoktatas/

- Hjort, Mette - Duncan Petrie: Introduction. The Cinema of Small Nations. Szerk. Mette Hjort and Duncan Petrie. Edinburgh, Edinburgh University Press, 2007. 1-19.

- Incze Kata: „Amit nem látunk, az nem történik meg.” Beszélgetés Nagy Zoltánnal, a Szép csendben rendezôjével. Filmtett, 2019. november 15. URL: https://www.filmtett.ro/cikk/amitnem-latunk-az-nem-tortenik-meg-nagy-zoltan-szep-csendben-interju/

- Kovács Bálint: De ugye nem nyúlt a testedhez úgy a tanárod? Kritika a Szép csendben címú filmról. Index, 2019. november 19.

https://index.hu/kultur/cinematrix/2019/11/19/szep_csendben_kritika_szexualis_zaklatas_metoo_magyar_filn

- Magyar Filmtudományi Társaság: Magyar Egyetemi Filmdíj. URL: https://www.filmtudomanyitarsasag.hu/oktatas/magyar-egyetemi-filmdij/

- Nestingen, Andrew: Crime and Fantasy in Scandinavia. Fiction, Film, and Social Change. Seattle, Washington University Press, 2008.

- Pócsik Andrea: Európaiság a (kritikai) filmoktatásban. Europe and European Cinema at Times of Change. Szerk. Zsolt Győri és György Kalmár. Debrecen, Debrecen University Press, 2021. 3948.

- Pócsik Andrea: Playing a Film Festival Jury: Cooperative Competition in the Classroom.

Alphaville: Journal of Film and Screen Media, 2017. tél (14). 202-206. URL: www.alphavillejournal.com/Issue14/Dossier.pdf

- Roxborough, Scott - Rhonda Richford: Europe's Bitter \#MeToo Debate: Bardot, Bertolucci and the "Threat of Change". The Hollywood Reporter, 2018. május 3. URL: https://www.hollywoodreporter.com/movies/movie-features/europes-bitter-metoo-debatebardot-bertolucci-threat-change-1107198/ 
- Soós Tamás: Élet, öröm, Auschwitz: A létezés eufóriája. Revizor, 2019. szeptember 11. URL: https://revizoronline.com/hu/cikk/8048/a-letezes-euforiaja/

- Stôhr Lóránt: Személyesség, jelenlét, narrativitás. Budapest, Gondolat, 2019.

- Szántó Eszter: Hartung Attila: Komoly lelkiismeret-furdalása volt a szereplôknek a forgatáson. 24.hu, 2019. november 05. https://24.hu/kultura/2019/10/05/hartung-attila-fomo-film-zgeneracio-interju/\#

- Virginás Andrea: Film Genres in Hungarian and Romanian Cinema. History, Theory, and Reception. Lanham, Lexington Books, 2021.

\section{Filmográfia}

- 1945 (Török Ferenc, 2017)

- A berlini követ (Szász Attila, 2014)

- A Hidember (Bereményi Géza, 2002)

- A létezés eufóriája (Szabó Réka, 2019)

- A napfény ize (Szabó István, 1999)

- A temetetlen halott (Mészáros Márta, 2004)

- A történet (The Tale. Jennifer Fox, 2018)

- Akik maradtak (Tóth Barnabás, 2019)

- Apró mesék (Szász Attila, 2019)

- Az asszisztens (The Assistant. Kitty Green, 2019)

- Botrány (Bombshell. Jay Roach, 2019)

- Cukorfalatok (Mignonnes. Maïmouna Doucouré, 2020)

- Csak családról ne (Kis Anna, 2019)

- És aztán táncoltunk (And Then We Danced. Levan Akin, 2020)

- Félvilág (Szász Attila, 2015)

- FOMO (Hartung Attila, 2019)

- Hajnali láz (Gárdos Péter, 2014)

- Hatalmas kis hazugságok (Big Little Lies. TV sorozat, Jean-Marc Vallée, 2017-2019)

- Hihetetlen (Unbelievable. TV sorozat, Lisa Cholodenko és Michael Dinner, 2019)

- Kincsem (Herendi Gábor, 2017)

- Kövek (Dobray György, 2020)

- Még egy kört mindenkinek (Druk. Thomas Vinterberg, 2020)

- Nagyi projekt (Révész Bálint, 2017)

- Örök tél (Szász Attila, 2018)

- Remélem legközelebb sikerül meghalnod:) (Schwechtje Mihály, 2018)

- Saul fia (Nemes Jeles László, 2015)

- Slalom (Charlène Favier, 2020)

- Sorstalanság (Koltai Lajos, 2005)

- Sóvirág (Szabó Réka, 2015)

- Szenvedély (Fehér György, 1998)

- Szép csendben (Nagy Zoltán, 2019)

- The Morning Show (TV sorozat, Mimi Leder és David Frankel, 2019-) 
(c) Apertúra, 2021. nyár | www.apertura.hu

webcím: https://www.apertura.hu/2021/nyar/gyori-magyar-egyetemi-filmdij-lehetseges-fogalmikeretek-es-tanusagok-2019-2021/

https://doi.org/10.31176/apertura.2021.16.4.2

(2)opertúro 